\title{
Upper Cenomanian-Lower Turonian ammonoids from the Saxonian Cretaceous (lower Elbtal Group, Saxony, Germany)
}

\author{
MARKUS WILMSEN \& EMAD NAGM
}

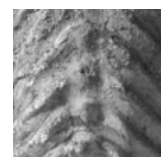

\begin{abstract}
The Upper Cenomanian to Lower Turonian ammonoid fauna of the Saxonian Cretaceous (Elbtal Group, Saxony, Germany) has been revised based on the study of 270 specimens hosted in the Museum für Mineralogie und Geologie (MMG) of the Senckenberg Naturhistorische Sammlungen Dresden. In total, 12 species have been identified and, based on this revision, a number of ammonoids are now reported and/or illustrated for the first time from the Elbtal Group of Saxony: Euomphaloceras septemseriatum, Neocardioceras juddii barroisi, Watinoceras coloradoense, Spathites (Jeanrogericeras) reveliereanus, Sciponoceras gracile and Scaphites equalis. The study demonstrated the presence of all Upper Cenomanian and Lower Turonian standard ammonite biozones in the lithostratigraphic succession of the lower Elbtal Group: the lower Upper Cenomanian Calycoceras naviculare Zone (represented by the Oberhäslich Formation), the mid- and upper Upper Cenomanian Metoicoceras geslinianum and Neocardioceras juddii zones (represented by the Dölzschen Formation), and the Lower Turonian Watinoceras coloradoense and Mammites nodosoides zones (represented by the Brießnitz Formation). The ammonoid fauna from the Saxonian Cretaceous is dominated by strongly ornamented and widely distributed Acanthoceratidae. $\bullet$ Key words: Upper Cretaceous, Saxo-Bohemian Cretaceous Basin, ammonites, taxonomic revision, biostratigraphy.
\end{abstract}

Wilmsen, M. \& NAGM, E. 2013. Upper Cenomanian-Lower Turonian ammonoids from the Saxonian Cretaceous (lower Elbtal Group, Saxony, Germany). Bulletin of Geosciences 88(3), 647-674 (18 figures). Czech Geological Survey, Prague. ISSN 1214-1119. Manuscript received September 26, 2012; accepted in revised form January 25, 2013; published online July 3, 2013; issued July 3, 2013.

Markus Wilmsen (corresponding author), Senckenberg Naturhistorische Sammlungen Dresden, Museum für Mineralogie und Geologie, Sektion Paläozoologie, Königsbrücker Landstr. 159, D-01109 Dresden, Germany; markus.wilmsen@senckenberg.de•Emad Nagm, Geology Department, Faculty of Science, Al-Azhar University, Assiut, Egypt; emad.nagm@yahoo.com

In Saxony, the area between Meißen, Dresden, Pirna and the Czech border is characterized by sedimentary rocks of early Late Cretaceous (Cenomanian-Lower Coniacian) age, more-or-less following the river Elbe valley (Fig. 1A). The lithofacies of these Cretaceous strata is dominated by marine siliciclastics and marls or marly limestones (so-called Pläner). Lithostratigraphically, they are combined in the so-called Elbtal Group (Tröger \& Voigt in Niebuhr et al. 2007), which forms an important link between the temperate Boreal shelf of northern and northwestern Europe and the Tethyan warm-water areas to the south. The Elbtal Group was deposited in a relatively narrow strait between the Westsudetic and the Mid-European islands and shows strong relationships in terms of facies and palaeontology to contemporaneous strata from the Bohemian Cretaceous Basin towards the southeast. The Saxonian Cretaceous is a classical topic of geognostic research in Germany and its palaeontology and stratigraphy have been studied in considerable detail (e.g., Geinitz 1839-1843, 1849, 1871-1875; Petrascheck 1902; Wanderer 1909; Tröger 1967, 1969, 2003).

The ammonites of the Saxonian Cretaceous have for the last time been monographed by Petrascheck (1902) over a century ago. Since those times, only some papers have been published dealing with individual taxa [e.g., Tröger 1968 on Hyphantoceras reussianum (d'Orbigny); Köhler 2001 on Turrilites (T.) cf. scheuchzerianus Bosc; Wilmsen \& Mosavinia 2011 on Schloenbachia varians (J. Sowerby)]. Thus, a comprehensive systematic revision was long overdue (for the Bohemian and Moravian part of the Saxo-Bohemian Cretaceous Basin, CenomanianLower Turonian ammonites have been revised in more recent times by Houša 1967; Konečný \& Vašíček 1983, 1987; and Vašíček 1989). In this first part, we focus on the Upper Cenomanian-Lower Turonian ammonite fauna. The few ammonites from the Lower Cenomanian Meißen 
Formation have been excluded from the revision; they have already been treated in some recent papers (Dietze 1960, Köhler 2001, Wilmsen \& Mosavinia 2011). A second part on the Middle-Upper Turonian ammonites of the Saxonian Cretaceous will follow (Nagm \& Wilmsen in prep.).

\section{Geological setting}

Palaeogeographically and in terms of (bio-)facies, the Elbtal Group is mediating between the Tethyan-influenced Bohemian Cretaceous in the southeast and the Boreal North German shelf sea in the northwest (Fig. 1B, C). The Saxonian Cretaceous Basin has a special palaeogeographic position between the Westsudetic Island in the northeast and the Osterzgebirge as an emergent part of the central Mid-European Island in the southwest. Today, the basin fill is preserved in a tectonic halfgraben, the active northeastern margin is represented by the Lausitz Fault (Fig. 1A). The facies and thickness changes of the Cretaceous strata within the Saxonian Cretaceous Basin show that at least from the Middle Turonian, deposition was influenced by syn-sedimentary activity of the Lausitz Fault (Voigt 1994, Kley \& Voigt 2008). The Lausitz Fault is joined by a number of other NW-SE-trending structural elements in Middle Europe (e.g., T. Voigt et al. 2006, Niebuhr et al. 2011) that have been characterized by compression since Turonian times (Kley \& Voigt 2008).

The following brief geological overview follows the revised lithostratigraphy of the Elbtal Group (Tröger \& Voigt in Niebuhr et al. 2007; see Fig. 2). A first marine transgression from the north took place in the late Early Cenomanian, reaching the area of Meißen (Meißen Formation). Conglomeratic bioclastic limestones indicate high-energy nearshore deposition. Marine Middle Cenomanian is unknown, but the back-filling of fluvial valleys (Niederschöna Formation; see Voigt 1998) indicates a continuing base-level rise. The major transgression occurred during the Late Cenomanian, submerging a pronounced relief of depressions and cliffs related to the different erosional resistance of the basement. In that time, a chain of isolated cliffs and islands was located at the southwestern margin of the basin (Voigt 1994, Voigt et al. 1994, S. Voigt et al. 2006, Wilmsen et al. 2011). Clastic sediments were predominantly sourced from the southwest (Osterzgebirge as a part of the Bohemian Massif) and the northeast (Westsudetic Island). The Late Cenomanian transgression took place in two major pulses: in the early Late Cenomanian (Calycoceras naviculare Zone), the shallow-marine conglomerates, fossiliferous sands and argillaceous silts of the Oberhäslich Formation ("Unterquader") have been deposited, usually missing on swells. The second pulse occurred in the Metoicoceras geslinianum Zone. This rapid (eustatic) rise of sea-level (plenus Transgression of authors) resulted in the drowning of many islands and the onlap of the Dölzschen Formation (proximal fine-grained sandstones grading into silty spiculitic marlstones; "Unterer Pläner" or "plenus-Pläner") onto formerly emergent basement areas, not only in Saxony but also in many parts of the Bohemian Cretaceous Basin (e.g., Žitt et al. $1998,2006,2010$ ) as well as on the opposite side of the Bohemian Massif in NE Bavaria (Wilmsen et al. 2010a, b; Richardt et al. 2013).

After the levelling of the pre-transgression topography during the Late Cenomanian, more uniform sedimentation patterns became established during the Turonian. In the Early Turonian, the still relatively narrow strait between the Westsudetic Island and the Bohemian Massif (Osterzgebirge) was characterized by cross-bedded, tidally influenced sands (Schmilka Formation; see Voigt 1999, Mitchell et al. 2010). These shallow-water deposits grade, with a transitional facies of bioturbated, silty-argillaceous, fine-grained sandstones and silts, into finegrained basinal deposits characterizing the "PlänerFazies" of the Dresden area (calcareous siltstones and silty marls of the Brießnitz Formation; Fig. 2). The Brießnitz Formation ranges into the lowermost Middle Turonian and is overlain by fine-grained, calcareous basinal deposits (Pläner sediments of the Räcknitz Formation) while in the Elbsandsteingebirge ("Saxonian Switzerland"), the sandstones, sandy marls and greensands of the Postelwitz Formation have been deposited, sourced from the rising Lausitz Massif.

\section{Conventions}

More than 270 specimens have been studied, mostly well to moderately well preserved (composite) internal moulds. All specimens, except one (Scaphites equalis Sowerby, M. Fengler collection, Dresden) are kept in the Museum für Mineralogie und Geologie (MMG) of the Senckenberg Naturhistorische Sammlungen Dresden (SNSD), Germany (repository SaK). Most of the ammonoids are historical specimens that have been collected in the nineteenth and twentieth century, and some of them have already been illustrated in earlier publications (Geinitz 1839-1843, 1849, 1871-1875; Petrascheck 1902; Wanderer 1909). If a specimen is re-figured herein, this is stated in the captions.

Suture terminology follows Wedekind (1916) as put forward by Kullman \& Wiedmann (1970) and revised in parts by Korn et al. (2003): E = external lobe, $\mathrm{A}=$ adventive lobe (= lateral lobe, L, of former nomenclature), $\mathrm{U}=$ umbilical lobe, I = internal lobe. A Vernier Caliper has been used to measure all linear dimensions (given in millimeters). Abbreviations are: maximum diameter $(\mathrm{D})$, whorl breadth $(\mathrm{Wb})$, 

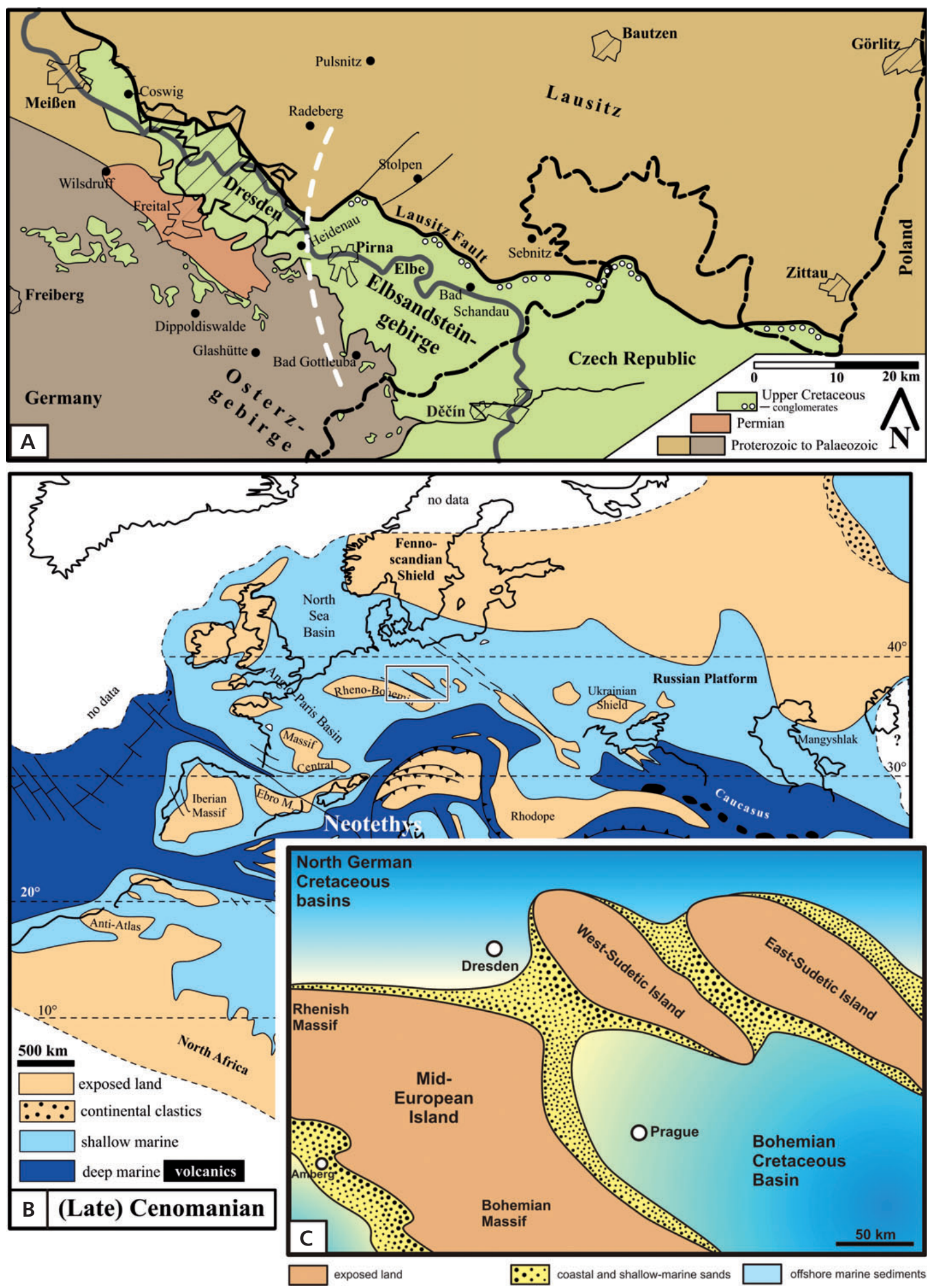

Figure 1. Regional and palaeogeographic framework. $\bullet$ A - distribution of the Cretaceous strata of the Elbtal Group (green) in Saxony; the dashed line separates the two principal lithofacies zones, i.e. sandy nearshore facies in the Saxonian Switzerland and marly offshore facies (Pläner) around Dresden (see Fig. 2). B - Late Cenomanian palaeogeography of northwestern Europe (modified after Philip \& Floquet 2000); the study area (see Fig. 1C) is indicated by a rectangle. $\bullet \mathrm{C}-$ detailed palaeogeography of the Saxo-Bohemian area (modified after Voigt 1994). 


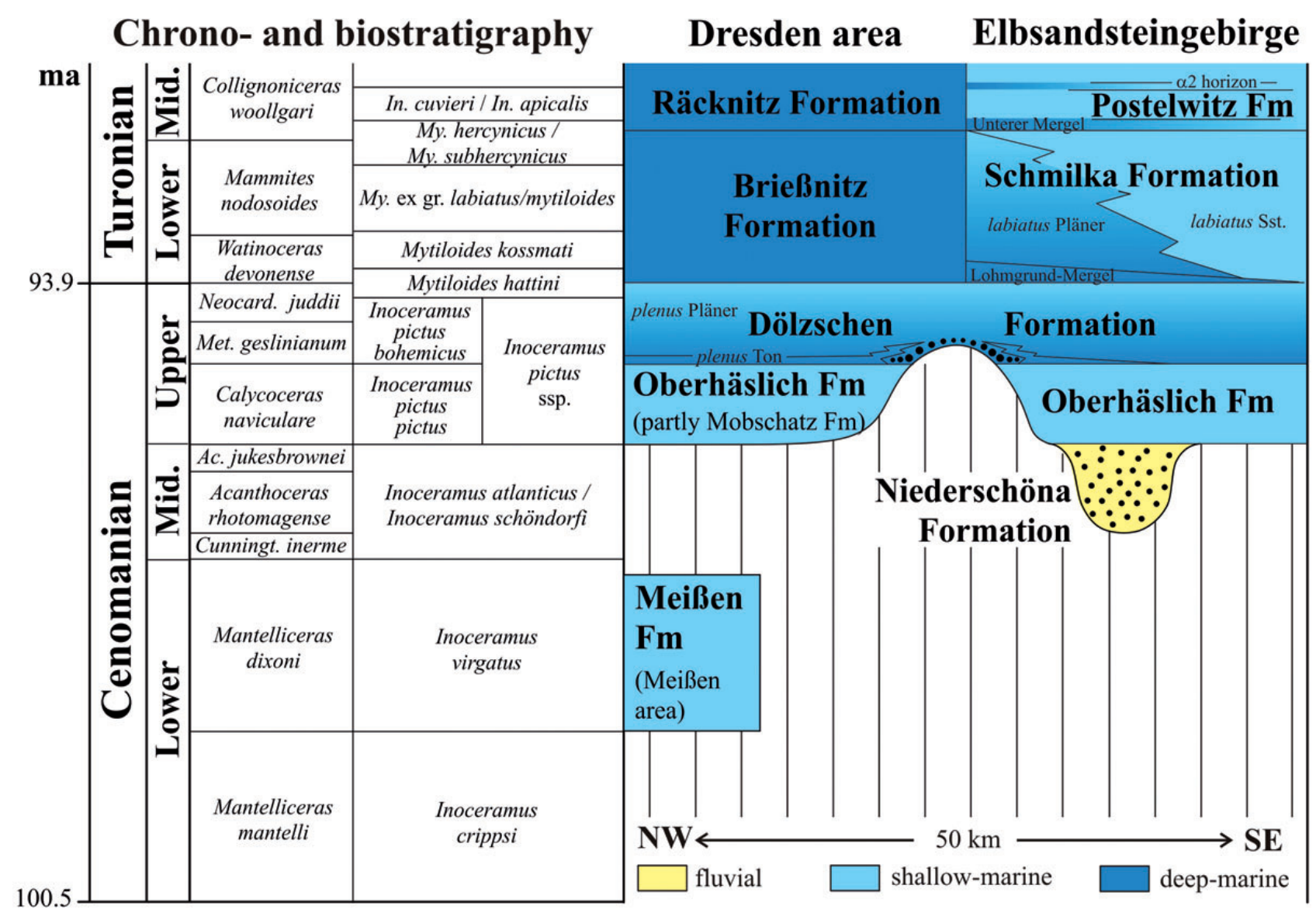

Figure 2. Stratigraphy of the lower part of the Elbtal Group (modified after Wilmsen \& Niebuhr 2009). Ammonite standard zones after Kennedy (1984, 1986), Wright et al. in Wright \& Kennedy (1984) and Hancock (1991), inoceramid zones after Tröger (1989), partly modified; absolute ages after Ogg \& Hinnov (2012).

whorl height (Wh), diameter of umbilicus (U). Figures in parentheses are dimensions as a percentage of diameter.

The terminology used for the description of the taxa and the systematics follows Wright et al. (1996). In order to keep this article as short as possible, the synonymies only contain the most recent ones as well as those being of regional interest or those being important for the discussion. Open nomenclature follows Bengtson (1988).

\section{Systematic palaeontology}

Order Ammonoidea Zittel, 1884

Suborder Ammonitina Hyatt, 1889

Superfamily Desmoceratoidea Zittel, 1895

Family Pachydiscidae Spath, 1922

\section{Genus Lewesiceras Spath, 1939}

Type species. - Ammonites peramplus Mantell, 1822, p. 200; by original designation.

Lewesiceras peramplum (Mantell, 1822)

Figures 3-5

*1822 Ammonites peramplus; Mantell, p. 200.

1871-72 Ammonites Lewesiensis Mnt. - Schlüter, p. 23, pl. 8, figs 5, 6 (non 7) [1871]; pl. 9, fig. 7 [1872].

1872 Ammonites peramplus Mant. - Fritsch, p. 38, figs 1-4.

1887 Pachydiscus peramplus Mantell sp. - Laube \& Bruder, p. 225, text-fig. 3a, b.

1887 Pachydiscus Lewesiensis Mantell sp. - Laube \& Bruder, p. 226, text-fig. 4a-c.

Figure 3. Lewesiceras peramplum (Mantell, 1822). • A - apertural view, B - lateral view, C - ventral view. MMG: SaK4039 (original of Petrascheck 1902, pl. 7, fig. 2, and probably of Wanderer, pl. 9, fig. 4). Upper Cenomanian Dölzschen Formation, Dresden-Ockerwitz. • D - lateral view; E - apertural view. MMG: SaK12100. Lower Turonian Brießnitz Formation, Dresden-Lockwitz. • F - lateral view; G - ventral view. MMG: SaK5350. Lower Turonian Brießnitz Formation, Dresden-Leubnitz. $\times 1$ 


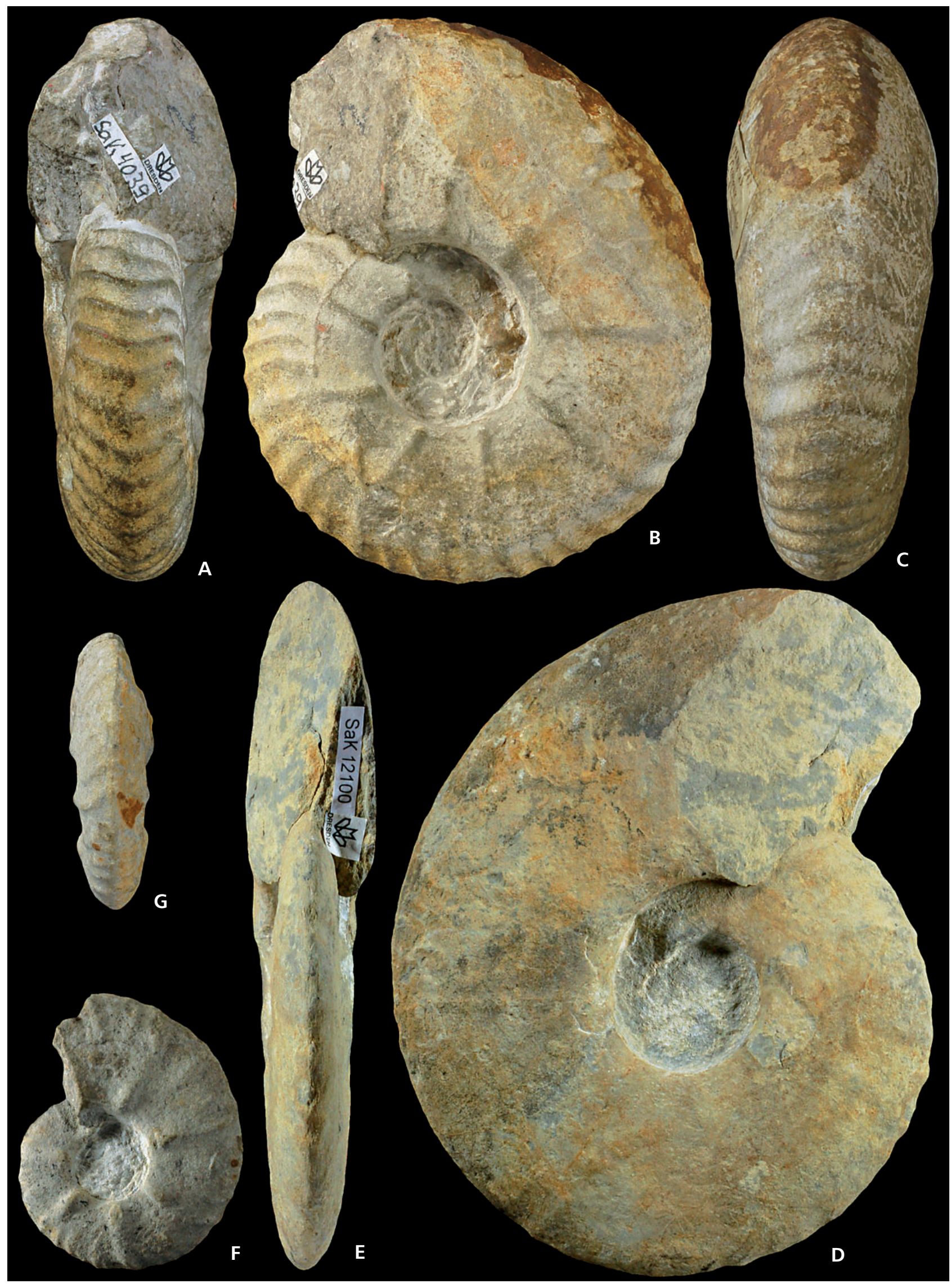




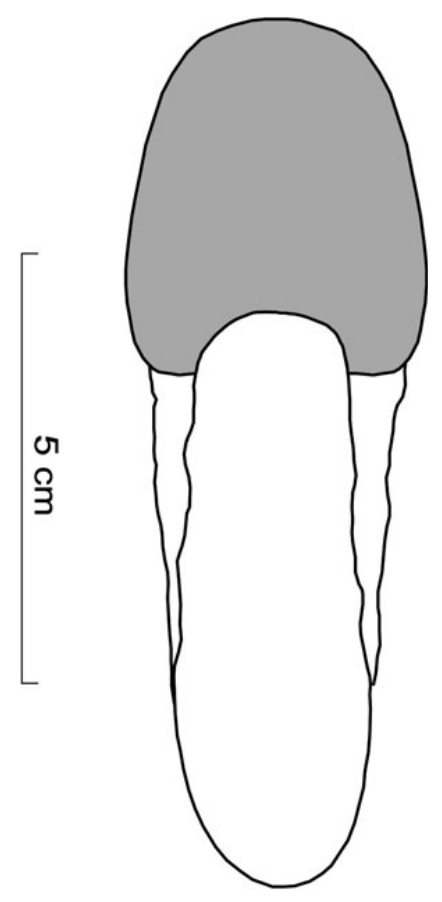

Figure 4. Whorl section of Lewesiceras peramplum (Mantell, 1822). MMG: SaK5559. Lower Turonian Brießnitz Formation, Dresden-Brießnitz.

1887 Pachydiscus juvencus; Laube \& Bruder, p. 228, pl. 29, fig. 1.

1902 Pachydiscus peramplus Mant. Spec. - Petrascheck, p. 137, pl. 7, fig. 2.

1909 Pachydiscus peramplus Mant. sp. - Wanderer, p. 62, pl. 9 , fig. 4.

1981 Lewesiceras peramplum (Mantell, 1822). - Wright \& Kennedy, p. 29, pl. 2, figs 1-3; pl. 3; text-figs 9, 12 (with synonymy).

1983 Lewesiceras peramplum (Mantell, 1822). - Konečný \& Vašíček, p. 176, pl. 3, fig. 1.

1987 Lewesiceras peramplum (Mantell, 1822). - Konečný \& Vašíček, p. 84, pl. 1, fig. 2.

1994 Lewesiceras peramplum (Mantell, 1822). - Chancellor et al., p. 22, pl. 3, figs 1-3.

2009 Lewesiceras peramplum (Mantell, 1822). - Lehmann \& Herbig, p. 64, pl. 1, figs H, I.

2012 Lewesiceras peramplum (Mantell, 1822). - Chrząstek, p. 88 , fig. $6 \mathrm{~A}-\mathrm{E}$.

Material. - Three specimens (SaK3181, 4022, 4039) from the Upper Cenomanian Dölzschen Formation in DresdenOckerwitz and Dresden-Leubnitz/Kauscha as well as in total 51 specimens from the Lower Turonian Brießnitz Formation in Dresden-Lockwitz (24 specimens), DresdenLeubnitz (22 specimens), Dresden-Cotta (3 specimens) and Dresden-Leutewitz (2 specimens). In addition to the three Cenomanian specimens, 32 specimens from the Lower Turonian have been measured (see below). 19 specimens (SaK5342, 5351, 5352, 12101, 12103, 12105, 12119, 12120, 12121, 12126, 12129, 12145, 12192, 12210, 12211, $12214,12232,14802,14893)$ are incomplete.
Measurements. -

Specimen D Wb Wh Wb/Wh U

$\begin{array}{llllll}\text { SaK5171 } 40.6(100) & 15.2(37.4) & 20.5(50.4) & 0.74 & 12.5(30.7)\end{array}$

$\begin{array}{lllllll}\text { SaK12245 } & 48.3(100) & 13.0(26.9) & 19.7(40.7) & 0.65 & 16.1(33.3)\end{array}$

$\begin{array}{llllll}\text { SaK5350 } & 50.2(100) & 13.3(26.4) & 22.0(43.8) & 0.60 & 14.1(28.0)\end{array}$

$\begin{array}{llllll}\text { SaK5343 } & 51.8(100) & 15.0(28.9) & 20.2(38.9) & 0.74 & 17.1(33.0)\end{array}$

$\begin{array}{lllllll}\text { SaK5530 } & 65.9(100) & 17.0(25.7) & 22.5(34.1) & 0.75 & 20.2(30.6)\end{array}$

$\begin{array}{lllllll}\text { SaK5345 } & 66.4(100) & 19.7(29.6) & 24.2(36.4) & 0.81 & 22.5(33.8)\end{array}$

$\begin{array}{lllllll}\text { SaK5440 } & 75.4(100) & 17.2(22.8) & 29.7(39.3) & 0.57 & 24.8(32.8)\end{array}$

$\begin{array}{lllllll}\text { SaK5341 } & 75.9(100) & 16.5(21.7) & 32.1(42.2) & 0.51 & 18.6(24.5)\end{array}$

$\begin{array}{lllllll}\text { SaK5166 } & 84.4(100) & 24.0(28.4) & 30.3(35.9) & 0.79 & 32.1(38.0)\end{array}$

$\begin{array}{lllllll}\text { SaK5384 } & 84.8(100) & 23.8(28.0) & 36.6(43.1) & 0.65 & 26.9(31.7)\end{array}$

$\begin{array}{lllllll}\text { SaK5180 } & 94.3(100) & 23.9(25.3) & 35.2(37.3) & 0.67 & 29.2(30.9)\end{array}$

$\begin{array}{llllllll}\text { SaK5279 } & 94.7(100) & 16.7(17.6) & 36.2(38.2) & 0.46 & 31.8(33.5)\end{array}$

$\begin{array}{lllllll}\text { SaK5349 } & 94.8(100) & 26.5(27.9) & 39.1(41.2) & 0.67 & 31.0(32.7)\end{array}$

$\begin{array}{lllllll}\text { SaK5559 } & 95.8(100) & 29.3(30.5) & 42.2(44.0) & 0.69 & 27.9(29.1)\end{array}$

$\begin{array}{llllll}\text { SaK12165 } & 96.4(100) & 25.9(26.8) & 41.0(42.5) & 0.63 & 28.7 \\ (29.7)\end{array}$

$\begin{array}{lllllll}\text { SaK5172 } & 97.9(100) & 25.0(25.5) & 42.4(43.3) & 0.58 & 30.0(30.6)\end{array}$

SaK4039 101.0 (100) $38.3(37.9) \quad 42.5(42.0) \quad 0.90 \quad 31.5(31.1)$

$\begin{array}{llllll}\text { SaK5522 } & 108.9(100) & 37.0(33.9) & 51.5(47.2) & 0.71 & 27.8(25.5)\end{array}$

$\begin{array}{llllll}\text { SaK5164 } & 111.0(100) & 30.3(27.2) & 51.4(46.3) & 0.58 & 32.1(28.9)\end{array}$

$\begin{array}{llllll}\text { SaK5373 } & 114.3(100) & 27.5(24.0) & 51.2(44.7) & 0.53 & 29.1(25.4)\end{array}$

SaK12235 117.0 (100) 26.2 (22.3) 47.4 (40.5) $0.55 \quad 32.2$ (27.5)

$\begin{array}{lllllll}\text { SaK5330 } & 123.4(100) & 27.9(22.6) & 60.6(49.1) & 0.46 & 38.2(30.9)\end{array}$

$\begin{array}{llllll}\mathrm{SaK} 12170 & 123.5(100) & 28.7(23.2) & 57.1(46.2) & 0.50 & 36.7 \\ (29.7)\end{array}$

$\begin{array}{llllll}\text { SaK5326 } & 126.0(100) & 36.4(28.8) & 55.2(43.8) & 0.65 & 38.3(30.3)\end{array}$

$\begin{array}{lllllll}\text { SaK5348 } & 132.1(100) & 32.9(24.9) & 56.8(42.9) & 0.57 & 39.7(30.0)\end{array}$

$\begin{array}{lllllll}\text { SaK12100 } & 132.3(100) & 23.4(17.6) & 57.0(43.0) & 0.41 & 35.5(26.8)\end{array}$

$\begin{array}{llllll}\text { SaK5325 } & 133.9(100) & 32.5(24.2) & 58.9 \text { (43.9) } & 0.55 & 45.1(33.6)\end{array}$

$\begin{array}{lllllll}S a K 14893 & 134.2(100) & 22.0(16.3) & 56.3(41.9) & 0.39 & 41.9(31.2)\end{array}$

$\begin{array}{lllllll}\text { SaK12229 } & 154.9(100) & 31.0(20.0) & 61.9(39.9) & 0.50 & 49.6(32.0)\end{array}$

$\begin{array}{lllllll}\text { SaK5353 } & 159.8(100) & 47.4(29.6) & 70.6(44.1) & 0.67 & 35.4(22.1)\end{array}$

$\begin{array}{llllll}\text { SaK3181 } & 172.0(100) & 43.8(25.4) & 65.8(38.2) & 0.66 & 53.9(31.3)\end{array}$

$\begin{array}{llllll}\text { SaK5163 } & 178.9(100) & 42.5(23.7) & 70.2(39.2) & 0.60 & 57.0(31.8)\end{array}$

$\begin{array}{llllll}\text { SaK4022 } & 193.8(100) & 40.0(20.6) & 82.2(42.4) & 0.48 & 54.5(28.1)\end{array}$

$\begin{array}{llllll}\text { SaK5444 } & 194.4(100) & 58.5(30.0) & 79.8(41.0) & 0.73 & 66.8(34.3)\end{array}$

$\begin{array}{lllllll}S a K 12190 & 225.4(100) & 43.0(19.0) & 95.1 & (42.1) & 0.45 & 66.6(29.5)\end{array}$

$\begin{array}{llllll}\text { average } & 112.9 & 28.3 & 47.5 & 0.61 & 34.1\end{array}$

Description. - Medium- to large-sized, with moderately evolute coiling (U $\sim 34 \%$ ) and steep umbilical wall. The whorl section is subcircular to high-oval (Fig. 4) and has a broadly rounded venter. Some specimens (e.g., SaK12100; Fig. 3D, E) are strongly compressed $(\mathrm{Wb} / \mathrm{Wh}<0.50)$ and have acute venters, related to lateral compaction (they are marked by italic font in the Measurements table). There are strong umbilical bullae on the inner flanks (about eight in SaK4039), giving rise to coarse prorsiradiate primaries; intercalated ribs arise on the middle flank and venter. All ribs are concave on the outer flank and convex across the venter. During ontogeny, the umbilical bullae fade and the ornament only consists of distant primary ribs. Sutures are not preserved. 
Remarks. - Lewesiceras peramplum is a very common species in Turonian successions of Germany. It has first been described by Schlüter (1871-1872) from the Lower Saxony Basin and by Petrascheck (1902) and Wanderer (1909) from the Saxonian Cretaceous Basin. In addition, it has been recorded from the Turonian of the Bohemian Cretaceous by Fritsch (1872), Laube \& Bruder (1887), Houša (1967, p. 10, pls 1-3, pl. 4, figs 1, 2, text-fig. 3) and Konečný \& Vašíček $(1983,1987)$. Most specimens have been collected from the Lower Turonian Brießnitz Formation. However, three specimens (SaK3181, 4022, 4039) are labeled to come from the Dölzschen Formation of DresdenOckerwitz (uppermost Cenomanian, Metoicoceras geslinianum and Neocardioceras juddii zones). If these data are correct, the range of Lewesiceras peramplum may be extended down into the upper Upper Cenomanian (also Wanderer 1909 reported records from the Cenomanian of Dresden-Ockerwitz). The studied material shows a variety in size from small- to large-sized and in shape from subcircular to strongly compressed whorl sections. Wright \& Kennedy (1981) have revised this species with a full discussion of its taxonomy and a recent discussion of the species has been provided by Chrzasstek (2012) based on occurrences from Poland.

Occurrence. - According to Wright \& Kennedy (1981), the species occurs abundantly in the Lower and Middle-lower Upper Turonian of Germany, the Czech Republic, Poland, France, Tunisia and Morocco. However, the first appearance date (FAD) of Lewesiceras peramplum may be already in the latest Cenomanian based on the potential records from the Dölzschen Formation in Saxony.

Superfamily Hoplitoidea Douvillé, 1890

Family Placenticeratidae Hyatt, 1900

\section{Genus Placenticeras Meek, 1876}

Type species. - Ammonites placenta DeKay, 1828, p. 278; by original designation.

\section{Placenticeras memoriaschloenbachi?}

\section{Laube \& Bruder, 1887}

Figures 6, 7A-B

1849 Ammonites bicurvatus Michelin. - Geinitz, p. 112, pl. 4, fig. 2a, b.

1875 Ammonites cf. bicurvatus Michelin, 1838. - Geinitz, p. 188 , pl. 34 , fig. 3 .

?*1887 Placenticeras Memoria-Schloenbachi; Laube \& Bruder, p. 221, pl. 23, figs 1a, b.

1909 Placenticeras memoria Schloenbachi Laube \& Bruder. - Wanderer, p. 61, pl. 9, fig. 3.
? 1981 Proplacenticeras cf. memoriaschloenbachi (Laube \& Bruder). - Kennedy et al., p. 31, pl. 23, figs 4, 5; text-fig. $11 \mathrm{~F}$.

? 1984 Placenticeras cf. memoriaschloenbachi Laube \& Bruder. - Kennedy \& Juignet, p. 107, figs 7a-i.

Material. - Two specimens (SaK2177, 4043) from the Upper Cenomanian Dölzschen Formation in Dresden-Plauen and Dresden-Ockerwitz, and two specimens (SaK12169, 12178) from the Lower Turonian Brießnitz Formation in Dresden-Lockwitz.

$\begin{array}{lcccccc}\text { Measurements. - } & & & & \\ \text { Specimen } & \mathrm{D} & \mathrm{Wb} & \mathrm{Wh} & \mathrm{Wb} / \mathrm{Wh} & \mathrm{U} \\ \text { SaK2177 } & 262.0(100) & 43.3(16.5) & 124.9(47.6) & 0.34 & 52.9 & (20.1)\end{array}$

Description. - The large specimens are characterized by involute coiling with a highly compressed oxycone whorl section (Fig. 6A). The umbilicus is relatively small ( $\mathrm{U} \leq 20 \%$ ) with steep umbilical wall and rounded umbilical shoulder. The flanks are wide, slightly concave, and smooth, with greatest breadth on the inner flanks. The venter is narrowly tabulate in SaK4043 and 12169 and sharp in the other two specimens (which may be a result of lateral compaction). The suture line (Fig. 6B) is incompletely preserved, but it shows the main sutural characters of the genus with strong subdivisions as well as narrow-necked lobes and saddles.

Remarks. - The species has first been described and illustrated from Saxony by Geinitz (1849) from the Cenomanian-Turonian boundary strata of Goppeln, south of Dresden, and assigned to A. bicurvatus Michelin, referring to pl. 84 in d'Orbigny (1841). However, this plate shows two different taxa from the Lower Cretaceous [Cleoniceras cleon (d'Orbigny) and Pseudosaynella bicurvata (Michelin)] that cannot be compared to the Late Cenomanian-Early Turonian specimens from Saxony. Laube \& Bruder (1887, p. 221) already discussed the affinitiy of A. bicurvatus as illustrated by Geinitz $(1849,1875)$ in the first description of Placenticeras Memoria-Schloenbachi, but pointed out the lack of the faint umibilical tubercles and the sharp venter in the Saxonian specimen (the latter is probably a result of taphonomic alteration). The material of the present study matches the stratigraphic position of, and is morphologically close to the type specimen as described and illustrated by Laube \& Bruder (1887) from the Lower Turonian of the Bohemian Cretaceous Basin, apart from the absence of the faint umbilical tubercles. We thus assign the specimens from Saxony to Laube \& Bruder's species only with hesitation. Kennedy et al. (1981) and Kennedy \& Juignet (1984) demonstrated that placenticeratids are characterized by considerable intraspecific variation from smooth oxyconic individuals with narrow tabulate venters to robust, ribbed, and tuberculate individuals. 
They described some specimens from France that they considered to be very closely related to Placenticeras memoriaschloenbachi, but also pointed out the need for a revision of Cenomanian-Turonian placenticeratids.

Occurrence. - The species has so far only been recorded from the Upper Cenomanian and Lower Turonian of Germany, the Czech Republic and France.

Superfamily Acanthoceratoidea de Grossouvre, 1894

Family Acanthoceratidae de Grossouvre, 1894

Subfamily Acanthoceratinae de Grossouvre, 1894

\section{Genus Neocardioceras Spath, 1926}

Type species. - Ammonites juddii Barrois \& Guerne, 1878, p. 46, pl. 1, figs 1, 2; by original designation.

\section{Neocardioceras juddii barroisi Wright \& Kennedy, 1981 Figures 7C-E, 8A}

1875 Ammonites Neptuni; Gein., p. 280, pl. 62, fig. 4A, B.

*1981 Neocardioceras juddii barroisi subsp. nov.; Wright \& Kennedy, p. 50, pl. 8, fig. 1, pl. 9, figs 4, 12-20, text-fig. 19J, L.

1986 Neocardioceras juddii barroisi Wright \& Kennedy.Kennedy, pl. 8, figs 4, 5 .

2003 Neocardioceras juddii barroisi Wright \& Kennedy, 1981. - Kennedy et al., p. 9, pl. 1, figs 7, 8.

Material. - One specimen (SaK1409) from the Dölzschen Formation of the Plauen'scher Grund in Dresden-Plauen.

\section{Measurements. -}

$\begin{array}{lrrrrr}\text { Specimen } & \mathrm{D} & \mathrm{Wb} & \mathrm{Wh} & \mathrm{Wb} / \mathrm{Wh} & \mathrm{U} \\ \mathrm{SaK} 1409 & - & 12.0 & 11.1 & 1.08 & -\end{array}$

Description. - The specimen is a small fragment, with nearly quadratic whorl section (Fig. 8A). The flanks are short and ornamented by dense, slightly flexed, coarse ribs, starting at the umbilical wall and persisting on the flanks and across the venter. The ribs are slightly prorsiradiate and project on the venter to join in chevron pattern. Each rib bears outer ventrolateral clavi and a siphonal clavus. Sutures are not preserved.

Remarks. - The present specimen has been described and illustrated by Geinitz (1875, p. 280, pl. 62, fig. 4A, B) as Ammonites neptuni. However, Subprionocyclus neptuni (Geinitz, 1849) is a Late Turonian species, having its stratum typicum in the lower part of the Strehlen Formation in Dresden (Kalkstein von Strehlen, mid-Upper Turonian). Wright \& Kennedy (1981) erected Neocardioceras juddii barroisi as a new subspecies to comprise the forms that are characterized by coarser and bluntly dense ribbing, less compressed whorl section and a more obtuse ventral chevron. These features are well developed in specimen SaK1409, and therefore, they considered the specimen illustrated by Geinitz (1875, pl. 62, fig. 4A, B) as N. juddii barroisi. Fig. 7C-E is the first photographic illustration of the specimen. The subspecies has also been described from northwest France (Kennedy et al. 2003, pl. 1, figs 7, 8).

Occurrence. - Neocardioceras juddii is the index fossil of the latest Cenomanian Neocardioceras juddii standard ammonite zone (see Kennedy 1984, Wright et al. in Wright \& Kennedy 1984 and Hancock 1991) and has been recorded from Germany, England, and France (Wright \& Kennedy 1981). This is the first proof of the N. juddii Zone in Saxony by means of ammonite evidence.

\section{Genus Watinoceras Warren, 1930}

Type species. - Watinoceras reesidei Warren, 1930, p. 67, pl. 3, fig. 2; pl. 4, figs 9-12; by original designation.

\section{Watinoceras coloradoense (Henderson, 1908)}

Figures 7F, 8B

1902 Schlönbachia gracillima Kossmat. - Petrascheck, p. 153 , pl. 9 , fig. $3 a$, b.

*1908 Acanthoceras coloradoense; Henderson, p. 259, pl. 13, figs 10, 11.

1972 Watinoceras coloradoense (Henderson). - Cobban \& Scott, p. 76, pl. 27, figs 11-19; pl. 28, figs 1-3, 5-9; text-figs 35-37.

1988 Watinoceras coloradoense (Henderson). - Cobban, p. 7, pl. 2, figs $1-23$; pl. 3, figs 4,5 ; text-fig. 4 (with full synonymy).

1994 Watinoceras coloradoense (Henderson, 1908). Chancellor et al., p. 24, pl. 2, figs 2-3.

2005 Watinoceras coloradoense (Henderson, 1908). Gale et al., p. 172, fig. 5A-D.

2007 Watinoceras coloradoense (Henderson, 1908). - Ifrim \& Stinnesbeck, p. 646, fig. 6A-C.

Figure 5. Lewesiceras peramplum (Mantell, 1822), × 1. • A - apertural view. MMG: SaK5176. Lower Turonian Brießnitz Formation, DresdenLeubnitz. $\bullet$ B - ventral view, C - lateral view. MMG: SaK5348. Lower Turonian Brießnitz Formation, Dresden-Leubnitz. $\bullet$ D - apertural view, E - lateral view, F - ventral view. MMG: SaK5559. Lower Turonian Brießnitz Formation, Dresden-Brießnitz. 


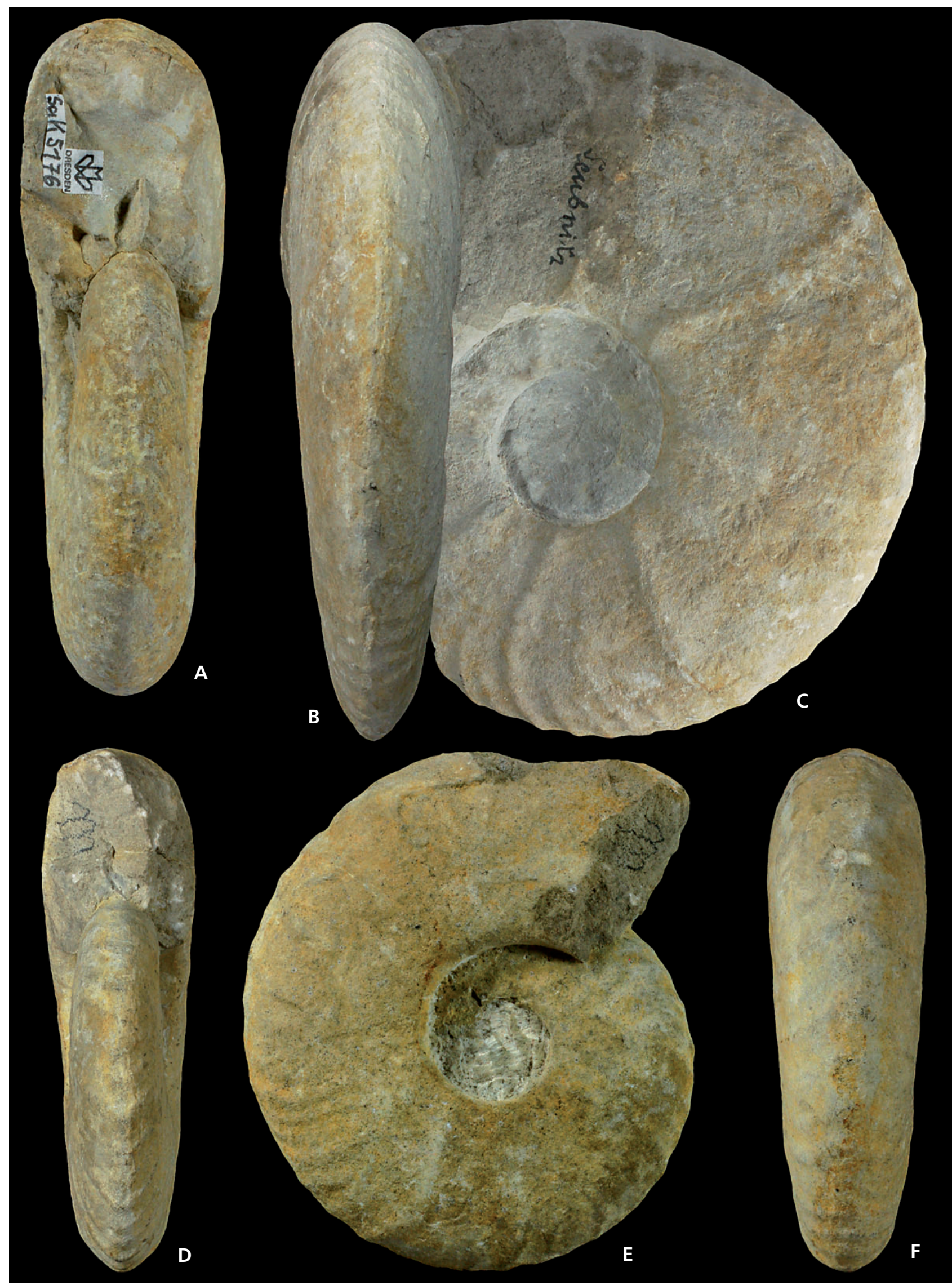




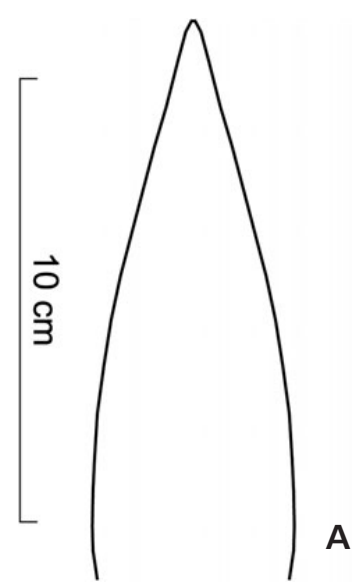

A
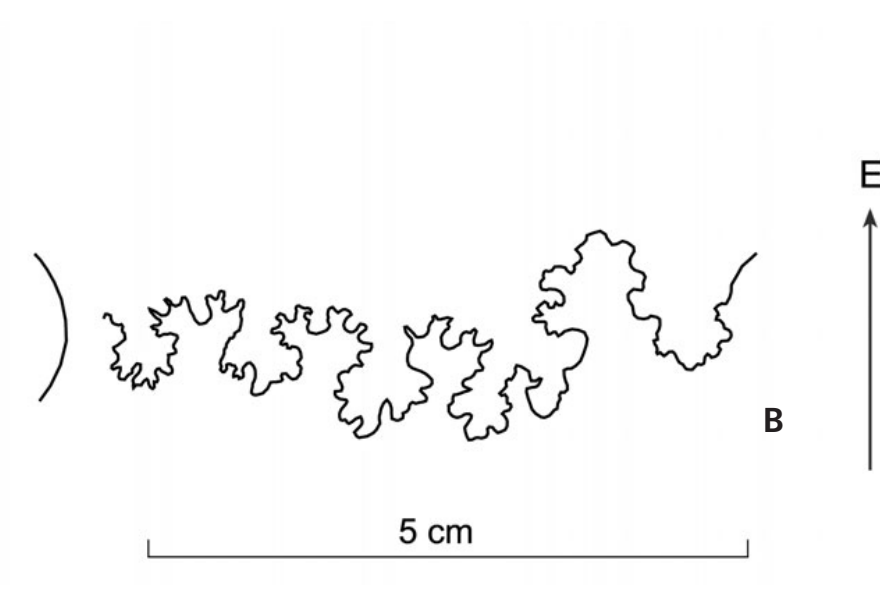

Figure 6. Placenticeras memoriaschloenbachi? Laube \& Bruder, 1887. • A - whorl section, B - incompletely preserved external suture line. MMG: SaK2177. Upper Cenomanian Dölzschen Formation, Dresden-Plauen.
Material. - A single specimen (SaK5517) from the Brießnitz Formation of Dresden-Cotta.

\section{Measurements. -}

$\begin{array}{llllll}\text { Specimen } & \mathrm{D} & \mathrm{Wb} & \mathrm{Wh} & \mathrm{Wb} / \mathrm{Wh} & \mathrm{U}\end{array}$

been discussed by Cobban (1988). Our single specimen is close to the nominate subspecies of Henderson (1908), but we refrain from a subspecific assignment.

Occurrence. - Watinoceras coloradoense is the index species of the early Early Turonian Watinoceras coloradoense/Watinoceras devonense Zone (Kennedy 1984, Hancock 1991). It has been recorded from Canada (Alberta, British Columbia), the United States (Colorado, Kansas, New Mexico), Mexico, Brazil, the Czech Republic, Turkestan, Uzbekistan and Tunisia. W. coloradoense is not well-known from Germany (there is a non-illustrated record by Skupin 1989 from the Münsterland Cretaceous Ba$\sin )$. This is the first record of the species from the Saxonian Cretaceous of Germany and the direct ammonite evidence of the presence of the $W$. coloradoense Zone.

\section{Genus Calycoceras Hyatt, 1900}

Type species. - Ammonites navicularis Mantell, 1822, p. 198, pl. 22, fig. 5; by original designation.

\section{Subgenus Calycoceras (Calycoceras) Hyatt, 1900}

Type species. - Ammonites navicularis Mantell, 1822, p. 198, pl. 22, fig. 5; by original designation.

\section{Calycoceras (Calycoceras) naviculare (Mantell, 1822)} Figures 9, 10

*1822 Ammonites navicularis; Mantell, p. 198, pl. 22, fig. 5.

Figure 7. A, B - Placenticeras memoriaschloenbachi? Laube \& Bruder, 1887. • A - ventral view, B - lateral view. MMG: SaK2177. Upper Cenomanian Dölzschen Formation, Dresden-Plauen, $\times$ 0.6. $\bullet$ C, D, E - Neocardioceras juddii barroisi Wright \& Kennedy, 1981. C, E - lateral views, D - ventral view. MMG: SaK1409 (original of Geinitz 1875, pl. 62, fig. 4). Upper Cenomanian Dölzschen Formation, Plauen'scher Grund in Dresden-Plauen, $\times 2$ 2. F - Watinoceras coloradoense (Henderson, 1908). Lateral view. MMG: SaK5517 (original of Petrascheck 1902, pl. 9, fig. 3). Lower Turonian Brießnitz Formation, Dresden-Cotta. $\times 1.5$. 


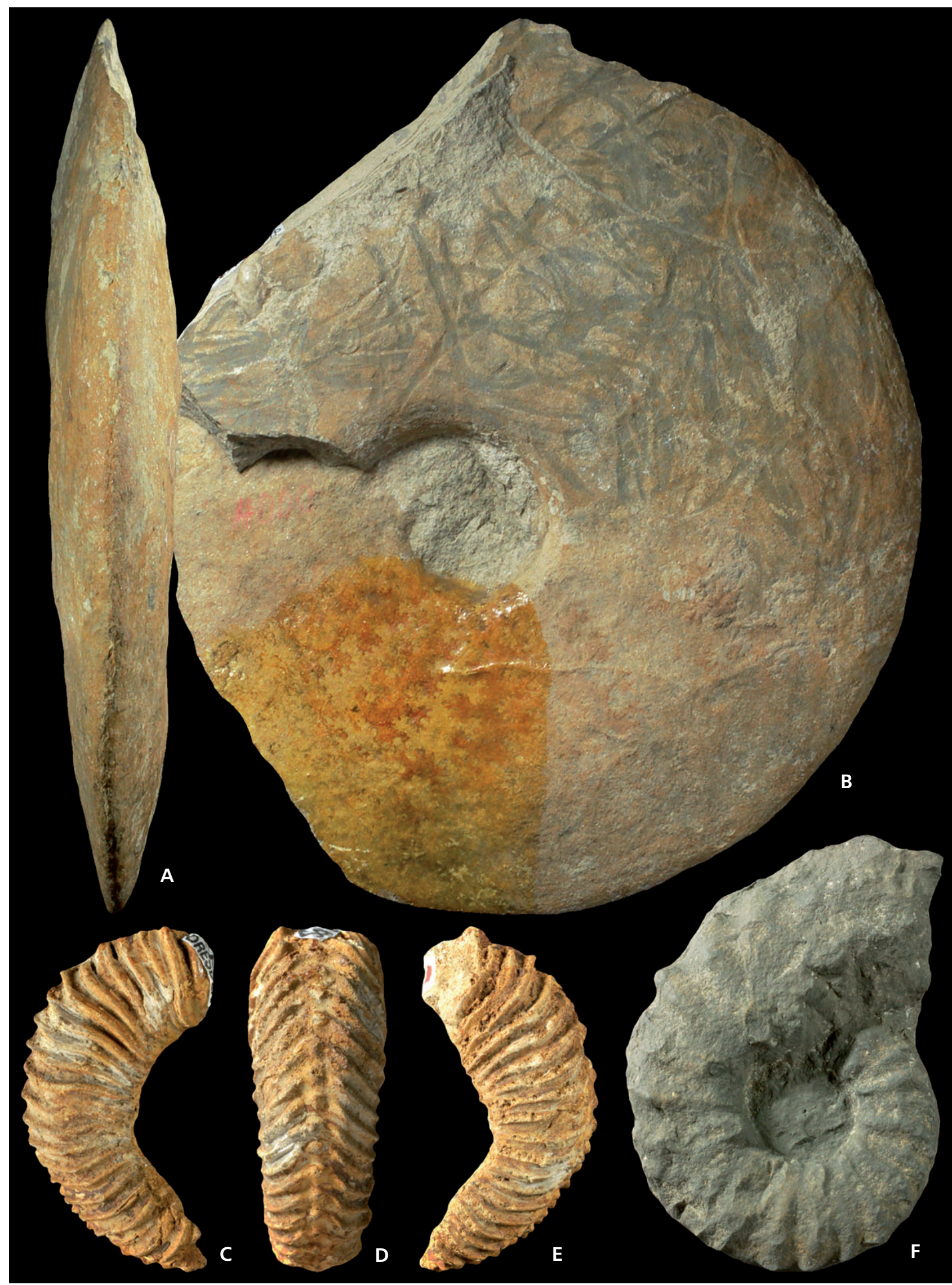




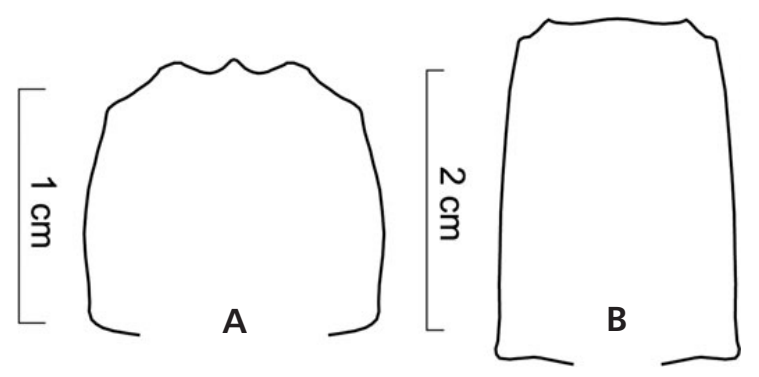

Figure 8. A - whorl section of Neocardioceras juddii barroisi Wright \& Kennedy, 1981. MMG: SaK1409. Upper Cenomanian Dölzschen Formation, Plauen'scher Grund in Dresden-Plauen. - B - whorl section of Watinoceras coloradoense (Henderson, 1908). MMG: SaK5517. Lower Turonian Brießnitz Formation, Dresden-Cotta.

1875 Ammonites Mantelli Sow. - Geinitz, p. 279, pl. 62, figs 1,2 .

1909 Douvilléiceras mantelli Sowerby sp. - Wanderer, p. 63 , pl. 11, fig. 1 .

1971 Calycoceras naviculare (Mantell). - Kennedy, p. 71, pl. 33, fig. 1a, b; pl. 34, fig. 1a, b; pl. 35, figs 1, 2; pl. 36, figs 1-4; pl. 37, figs 1-3; pl. 47, figs 1, 3, 5 .

1981 Calycoceras (Calycoceras) naviculare (Mantell, 1822). - Kennedy \& Juignet, p. 29, fig. 6b, c.

1981 Calycoceras (Calycoceras) naviculare (Mantell, 1822). - Wright \& Kennedy, p. 34, pl. 4; pl. 5, figs 1-3; text-figs $13,14 \mathrm{c}-\mathrm{e}$ (with full synonymy).

1989 Calycoceras (Calycoceras) naviculare (Mantell, 1822). - Cobban et al., p. 24, fig. 70A-T.

1990 Calycoceras (Calycoceras) naviculare (Mantell, 1822). - Wright \& Kennedy, p. 236, pl. 61, fig. 1; pl. 62, figs 1-6; pl. 63, figs 1-3; text-figs 88E, I, $89 \mathrm{D}, 110 \mathrm{C}$.

1998 Calycoceras (Calycoceras) naviculare (Mantell, 1822). - Kaplan et al., p. 152, pl. 53.

2004 Calycoceras (Calycoceras) naviculare (Mantell, 1822). - Barroso-Barcenilla, p. 89, pl. 1, fig. 2.

Material. - Five specimens (SaK4021, 4415, 4515, 4652, 5650) from the Oberhäslich Formation of Welschhufe near Bannewitz, south of Dresden, and two specimens (SaK4706, 4705) from the Dölzschen Formation of the Oberau railway tunnel near Meißen. All specimens are from the Upper Cenomanian.

\section{Measurements. -}

Specimen $\quad \mathrm{D} \quad \mathrm{Wb} \quad \mathrm{Wh} \quad \mathrm{Wb} / \mathrm{Wh} \quad \mathrm{U}$

$\begin{array}{llllll}\text { SaK4706 } & 64.9(100) & 29.1(44.8) & 25.4(39.1) & 1.14 & 18.0(27.7)\end{array}$

$\begin{array}{llllll}\text { SaK5650 } & 176.1(100) & 79.0(44.8) & 71.3(40.4) & 1.10 & 46.1(26.1)\end{array}$

Description. - The specimens are characterized by moderately evolute coiling. The depressed whorl section has its greatest whorl breadth on the lower flank (Fig. 9). The umbilicus is deep, with rounded, slightly overhanging wall. Strong primary ribs arise at the umbilical wall and carry

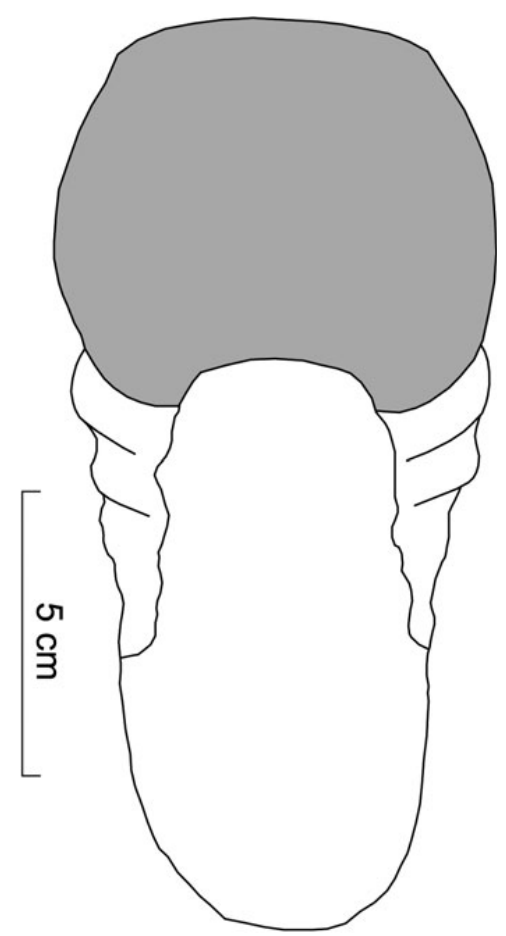

Figure 9. Whorl section of Calycoceras (Calycoceras) naviculare (Mantell, 1822). MMG: SaK5650 (original of Geinitz 1875, pl. 62, figs 1, 2). Upper Cenomanian Oberhäslich Formation, Welschhufe near Bannewitz (south of Dresden).

rounded umbilical bullae. Short and likewise strong secondary ribs are intercalated. All ribs are rectiradiate and number about 30 per whorl at D = $176 \mathrm{~mm}$ in SaK5650, separated by intercostal spaces of similar width. Flanks are short, convex and smoothly connected to the wide and arched venter by means of weak ventrolateral shoulders. None of the specimens shows sutures.

Remarks. - Specimen SaK5650 is the original of Geinitz (1875, pl. 62, figs 1a, b) and has been misidentified as "Ammonites mantelli Sow.”. However, Mantelliceras mantelli (J. Sowerby, 1814) is an index species of the Lower Cenomanian and characterized by completely different ribbing and tuberculation patterns (e.g., Wright \& Kennedy 1984, but note that Ammonites mantelli Sow. of Geinitz has there been placed in the synonymy of M. mantelli). Barroso-Barcenilla (2004) noted that mainly due to the poor quality of Mantell's (1822) original illustration and the lack of a precise description of the holotype, the definition of Calycoceras (Calycoceras) naviculare has led to different interpretations, mainly during the nineteenth century and first half of the twentieth century. Consequently, numerous specimens assigned to the species have been shown to belong to different taxa. This confusing situation has also caused considerable variations in the synonymy from author to author. Therefore, the specific differences that distinguish Calycoceras (Calycoceras) naviculare from other species of the (sub-)genus have been discussed in 


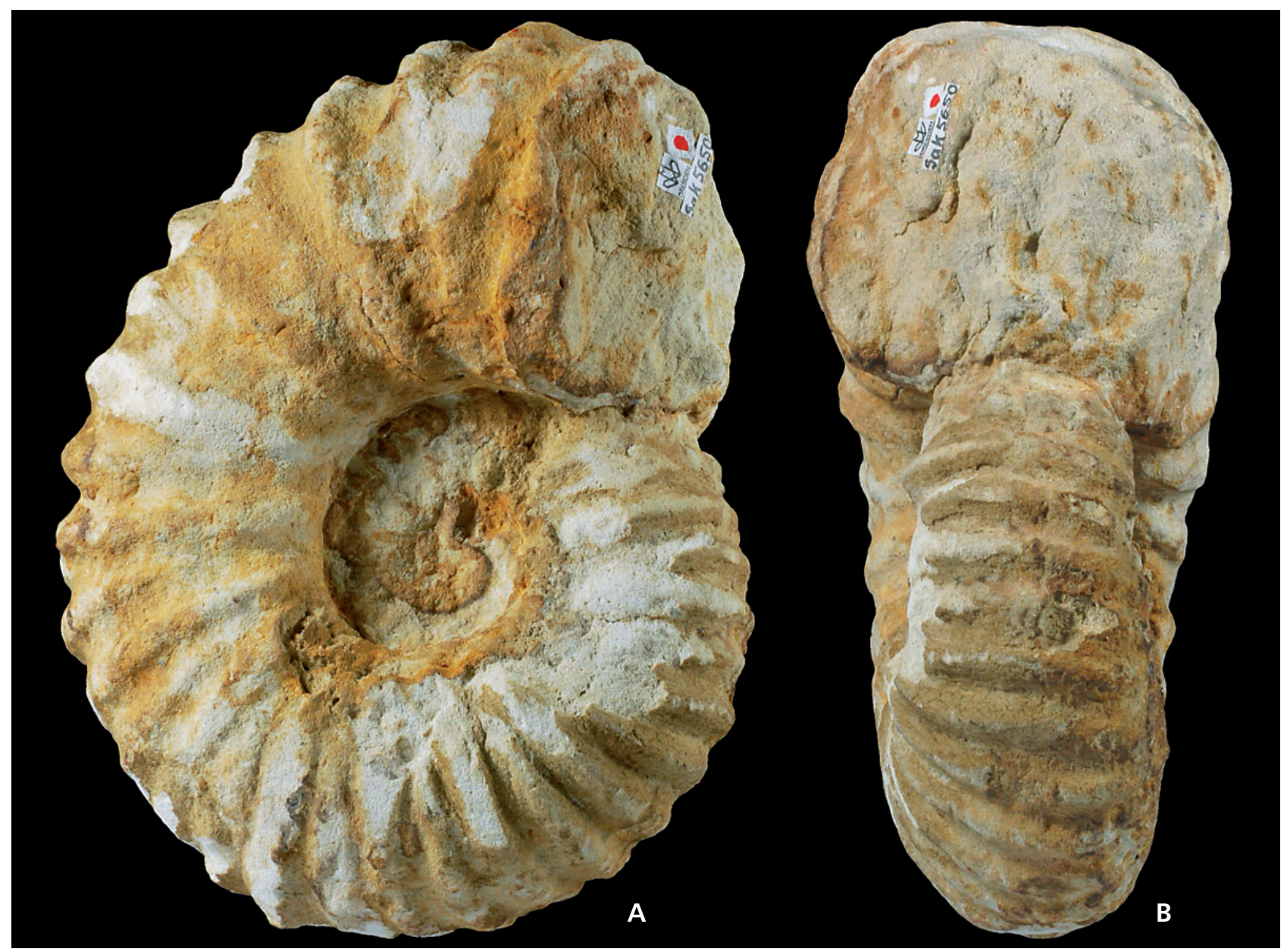

Figure 10. Calycoceras (Calycoceras) naviculare (Mantell, 1822). A - lateral view, B - apertural view. MMG: SaK5650 (original of Geinitz 1875 , pl. 62, figs 1, 2). Upper Cenomanian Oberhäslich Formation, Welschhufe near Bannewitz (south of Dresden). $\times 1$.

detail by Wright \& Kennedy (1981, 1990). The few specimens from Saxony match well to the descriptions and illustrations provided in these revisions.

Occurrence. - Calycoceras (Calycoceras) naviculare is a widespread index species for the early Late Cenomanian Calycoceras $(C$.) naviculare Zone [or its equivalent Calycoceras (Proeucalycoceras) guerangeri Zone; see Kennedy 1984; Wright et al. in Wright \& Kennedy 1984; Hancock 1991]. The five specimens from Welschhufe document this zone for the Oberhäslich Formation (where they are associated with typical low-Upper Cenomanian representatives of the Inoceramus pictus group). However, the species ranges into the overlying M. geslinianum Zone (Wright \& Kennedy 1981) and the two specimens from the Dölzschen Formation of the Oberau railway tunnel are from this stratigraphically higher level. Calycoceras $(C$.) naviculare occurs in Germany, England, France, Spain, Portugal, northern Africa, the United States (Colorado, Kansas, New Mexico, Texas and California), Japan, India, Iran, Angola, and Madagascar (Wright \& Kennedy 1981, 1990).
Subfamily Euomphaloceratinae Cooper, 1978

\section{Genus Euomphaloceras Spath, 1923}

Type species. - Ammonites euomphalus Sharpe, 1855, p. 31 , pl. 13, fig. 4; by monotypy.

\section{Euomphaloceras septemseriatum (Cragin, 1893)}

Figure 12C

*1893 Scaphites septem-seriatus; Cragin, p. 240.

1978 Euomphaloceras (Kanabiceras) septem-seriatum (Cragin, 1893). - Cooper, p. 106, figs 4N-O, 10A-E, 12E-H, 18G-H, 19G-L, 26A-B, 28.

1981 Euomphaloceras septemseriatum (Cragin, 1893). Kennedy \& Juignet, p. 38, fig. 9b-d.

1981 Euomphaloceras septemseriatum (Cragin, 1893). Wright \& Kennedy, p. 55, pl. 12, figs 1-8; pl. 13, figs 1-6; pl. 14, figs 5-9 (with full synonymy).

1988 Euomphaloceras septemseriatum (Cragin, 1893). Kennedy, p. 53, pl. 8, figs 1-6, 9; pl. 9, figs 1-3, 5-7, 


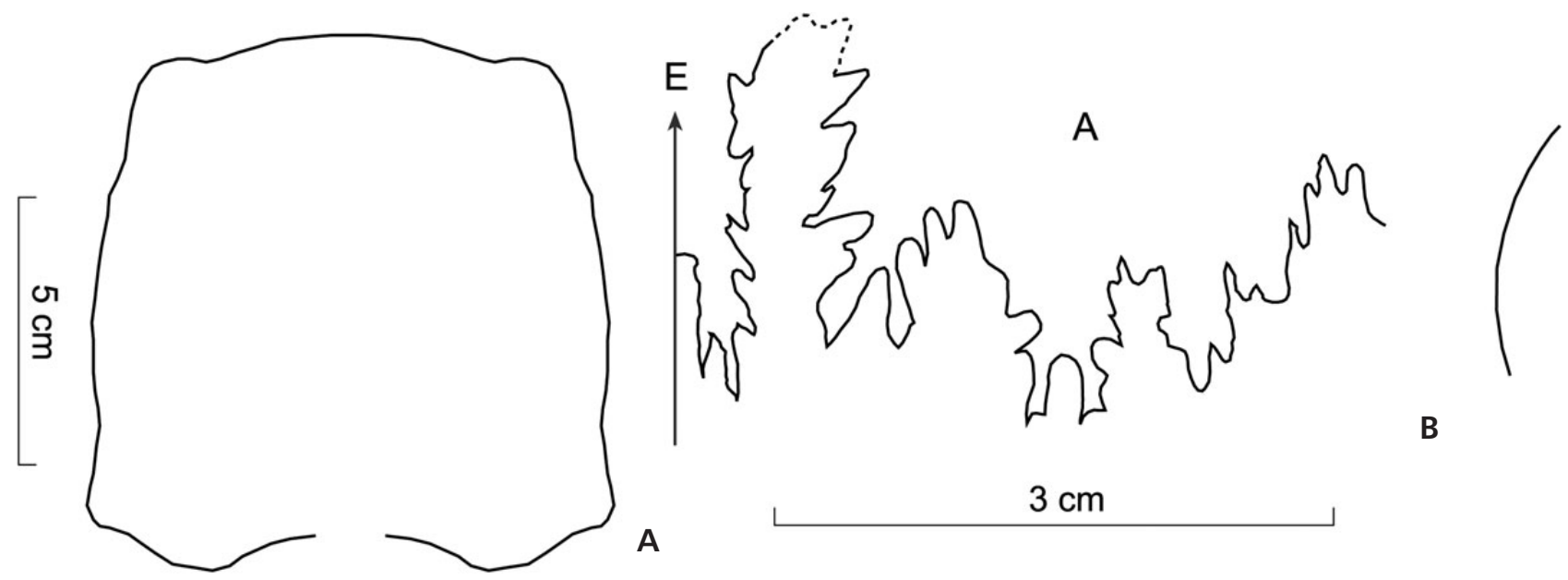

Figure 11. Pseudaspidoceras footeanum (Stoliczka, 1864). • A - whorl section, B - external suture line. MMG: SaK4799. Lower Turonian Brießnitz Formation, Dresden-Gorbitz.

9-12; pl. 22, fig. 3; text-figs 10E, 11D (with full synonymy).

1989 Euomphaloceras septemseriatum (Cragin). - Cobban et al., p. 35, figs 35, 76Q-T, Z-FF, HH-PP.

2003 Euomphaloceras septemseriatum (Cragin, 1893). Kennedy et al., p. 10, pl. 2, figs 9, 10, 13, 15, 18-23.

2010 Euomphaloceras septemseriatum (Cragin, 1893). Nagm et al., p. 479, figs 5I-K, 7C.

Material. - One fragmentarily preserved specimen (SaK7849) from the Dölzschen Formation of the Ratssteinbruch in Dresden-Plauen.

Description. - Even in fragmentary preservation, specimen SaK7849 shows the main characters of the species, represented by fine ribs arising at the umbilical margin and persisting on the flanks up to the wide, flat venter. Each rib carries small umbilical bullae, strong inner ventrolateral tubercles, oblique outer ventrolateral bullae, and small, rounded siphonal tubercles. The outer ventrolateral bullae and the siphonal tubercles are very close. Thus, ventrally there is a characteristic central band of three rows of tubercles.

Remarks. - Several authors have described the species in detail (e.g., Cooper 1978, Wright \& Kennedy 1981, Kennedy 1988), and already Kennedy et al. (1981) noted that Euomphaloceras septemseriatum shows considerable morphological variation. New data on E. septemseriatum provided by Kennedy (1988) based on material from Texas show that this is a markedly dimorphic species. The very conspicuous ventral morphology allows a safe assignment of our single specimen to E. septemseriatum.

Occurrence. - Euomphaloceras septemseriatum is widespread in the Late Cenomanian Metoicoceras geslinianum Zone (Kennedy 1984; Wright et al. in Wright \& Kennedy 1984; Hancock 1991) and has records in Germany, England, France, United States (Texas, New Mexico, Arizona, Colorado, Kansas, Montana, Utah, California), Brazil, Japan, Egypt, Nigeria and Angola. The occurrence in the Dölzschen Formation of the Ratssteinbruch in Dresden-Plauen represents the first record of the species from Saxony.

\section{Genus Pseudaspidoceras Hyatt, 1903}

Type species. - Ammonites footeanus Stoliczka, 1864, p. 101, pl. 52, figs 1, 1a-c, 2, 2a; by original designation.

\section{Pseudaspidoceras footeanum (Stoliczka, 1864)}

Figures 11, 12A-B

*1864 Ammonites Footeanus; Stoliczka, p. 101; pl. 52, figs 1-2.

1902 Mammites Footeanus Stol. spec. - Petrascheck, p. 144, pl. 9, fig. 1a, b.

1982 Pseudaspidoceras footeanum (Stoliczka). - Chancellor, p. 92, figs 2A, 24, 25.

Figure 12. A, B - Pseudaspidoceras footeanum (Stoliczka, 1864). A - lateral view, B - ventral view. MMG: SaK4799 (original of Petrascheck 1902 , pl. 9, fig. 1). Lower Turonian Brießnitz Formation, Dresden-Gorbitz. $\times 0.65 . \bullet C-$ Euomphaloceras septemseriatum (Cragin, 1893). Lateral view. MMG: SaK7849. Upper Cenomanian Dölzschen Formation, Dresden-Plauen, $\times 1$. D , E - Metoicoceras geslinianum (d'Orbigny, 1850); D - lateral view, E - ventral view. MMG: SaK4045. Upper Cenomanian Dölzschen Formation, Dresden-Ockerwitz. $\times 1$. 


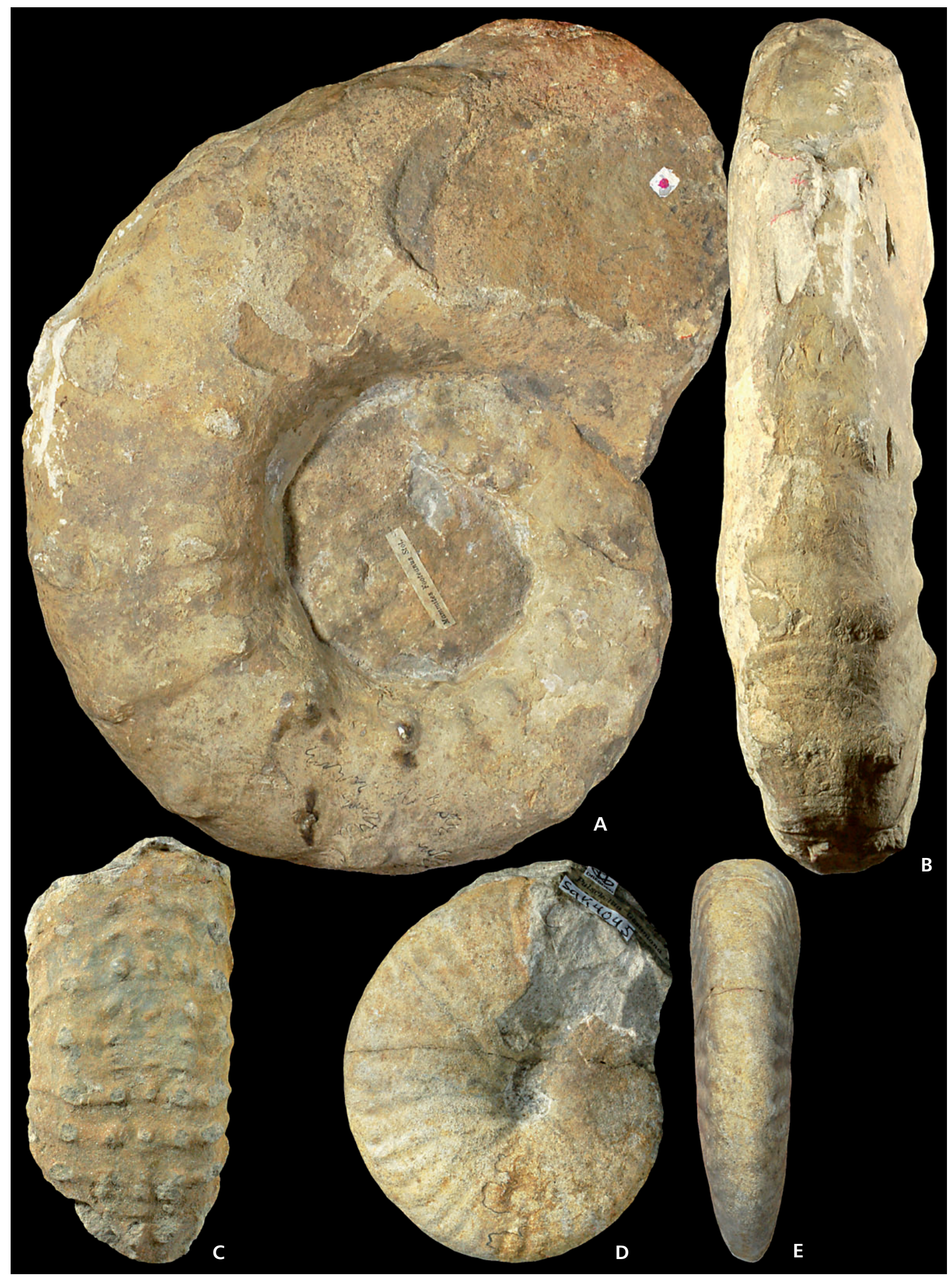




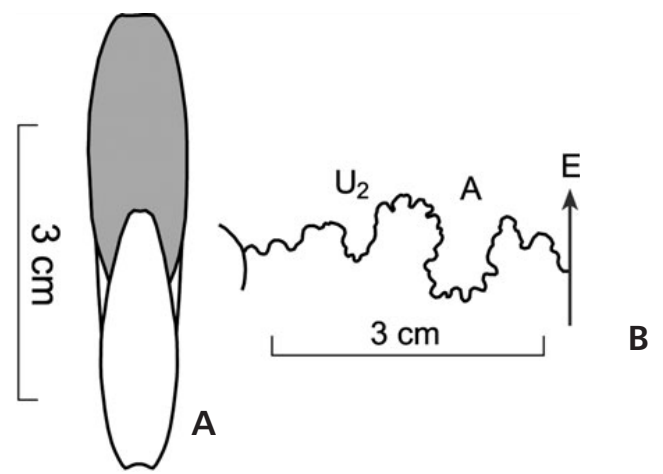

Figure 13. Metoicoceras geslinianum (d'Orbigny, 1850). • A - whorl section, B - external suture line. MMG: SaK4045 (original of Petrascheck 1902, pl. 7, fig. 4). Upper Cenomanian Dölzschen Formation, DresdenOckerwitz.

1985 Pseudaspidoceras footeanum (Stoliczka). - Howarth, p. 98, figs 30-33.

1995 Pseudaspidoceras footeanum (Stoliczka, 1864). Zaborski, p. 59, figs 6, 7, 9, 10.

2009 Pseudaspidoceras footeanum (Stoliczka, 1864). Lehmann \& Herbig, p. 67, pl. 1, figs P-Q; text-fig. 7B.

Material. - Three specimens (SaK4799, 5526, 5465) from the Lower Turonian Brießnitz Formation in DresdenGorbitz, Dresden-Omsewitz and Dresden-Cotta.

Measurements. -

$\begin{array}{lccccc}\text { Specimen } & \mathrm{D} & \mathrm{Wb} & \mathrm{Wh} & \mathrm{Wb} / \mathrm{Wh} & \mathrm{U} \\ \text { SaK4799 } & 245.5(100) & 48.6(19.7) & 53.3(21.7) & 0.91 & 89.9(36.6) \\ \text { SaK5526 } & 130.2(100) & 32.4(24.8) & 48.1(36.9) & 0.67 & 51.1(39.2)\end{array}$

Description. - The large specimens are characterized by evolute coiling with a wide, deep umbilicus and a concave umbilical wall. The whorls are sub-quadratic (Fig. 11A), with the greatest breadth at the umbilical tubercles. Very low, weak and wide ribs ornament the flat flanks. These ribs arising at the umbilical seam and strengthen into strong tubercles on the umbilical shoulder. Inner ventrolateral tubercles, with the same number and size of the umbilical ones, mark the ventrolateral shoulder. The venter is rounded and bound with small outer ventrolateral tubercles. The suture line (Fig. 11B) is characterized by a very wide adventive lobe and a high and narrow external saddle.

Remarks. - The similarities and differences between Pseudaspidoceras footeanum and other species of the genus (e.g. P. flexuosum, P. paganum, P. ressidei, P. barberi have been thoroughly discussed in several papers (Wright \& Kennedy 1981, Zaborski 1995, Lehmann \& Herbig 2009). In terms of morphological characters (e.g., whorl section, umbilical width, ribbing), the specimens from the Saxonian Cretaceous can be unequivocally assigned to $P$. footeanum. Specimen SaK4799 has already been described and illustrated by Petrascheck (1902). It differs from the specimen described and illustrated as $P$. cf. footeanum by Wright \& Kennedy (1981, pl. 21, fig. 3a, b) by means of its stronger compression, degree of involution and less pronounced tuberculation.

Occurrence. - Pseudaspidoceras footeanum occurs in the Lower Turonian of Germany, England, Brazil, Mexico, India, Israel, Angola, Nigeria and Morocco (e.g., Zaborski 1995, Lehmann \& Herbig 2009).

Subfamily Mammitinae Hyatt, 1900

\section{Genus Metoicoceras Hyatt, 1903}

Type species. - Ammonites swallovi Shumard, 1860, p. 591; by subsequent designation (Shimer \& Shrock 1944, p. 591).

Metoicoceras geslinianum (d'Orbigny, 1850)

Figures 12D, E, 13, 14

*1850 Ammonites Geslinianus; d'Orbigny, p. 146.

1875 Ammonites Geslianus [sic] d'Orb. - Geinitz, p. 280, pl. 62 , fig. 3.

1902 Pulchellia Gesliniana d'Orb. spec. - Petrascheck, p. 140, pl. 7, figs 3a, b, 4a, b, 5a, b.

1909 Pulchellia Gesliana [sic] d'Orbigny sp. - Wanderer, p. 63 , pl. 9 , fig. 5 .

1981 Metoicoceras geslinianum (d'Orbigny). - Kennedy et al., p. 60, pl. 3, figs 6-8; pl. 9, figs 1, 2; pl. 10, figs 5 , 6; pls $11-13$; pl. 14 , figs $1-3$; pl. 15 , figs $1-3$; pl. 16; pl. 17, figs 1-3; text-figs 13-17 (with full synonymy).

1981 Metoicoceras geslinianum (d'Orbigny, 1850). Wright \& Kennedy, p. 62, pl. 17, fig. 2; pl. 18, figs 1 , 2; pl. 19, figs 1, 2; pl. 20, figs 1-3; pl. 21, figs 1,2 ; text-figs 19C-E, 20, 21A-D.

1981 Metoicoceras geslinianum (d'Orbigny, 1850). - Kennedy \& Juignet, p. 39, figs 7d, e, 8a-c, 9a, e, 10a.

Figure 14. Metoicoceras geslinianum (d'Orbigny, 1850). A - ventral view, B - lateral view. MMG: SaK641 (original of Geinitz 1875, pl. 62, fig. 3). Upper Cenomanian Dölzschen Formation, Welschhufe near Bannewitz (south of Dresden). $\bullet$ - lateral view, D - ventral view. MMG: SaK4040 (original of Petrascheck 1902, pl. 7, fig. 5). Upper Cenomanian Dölzschen Formation, Dresden-Ockerwitz. • E, G - lateral views, F - ventral view. MMG: SaK4041 (original of Petrascheck 1902, pl. 7, fig. 3). Upper Cenomanian Dölzschen Formation, Dresden-Ockerwitz. • H - lateral view. MMG: SaK4045 (original of Petrascheck 1902, pl. 7, fig. 4). Upper Cenomanian Dölzschen Formation, Dresden-Ockerwitz. × 1 . 


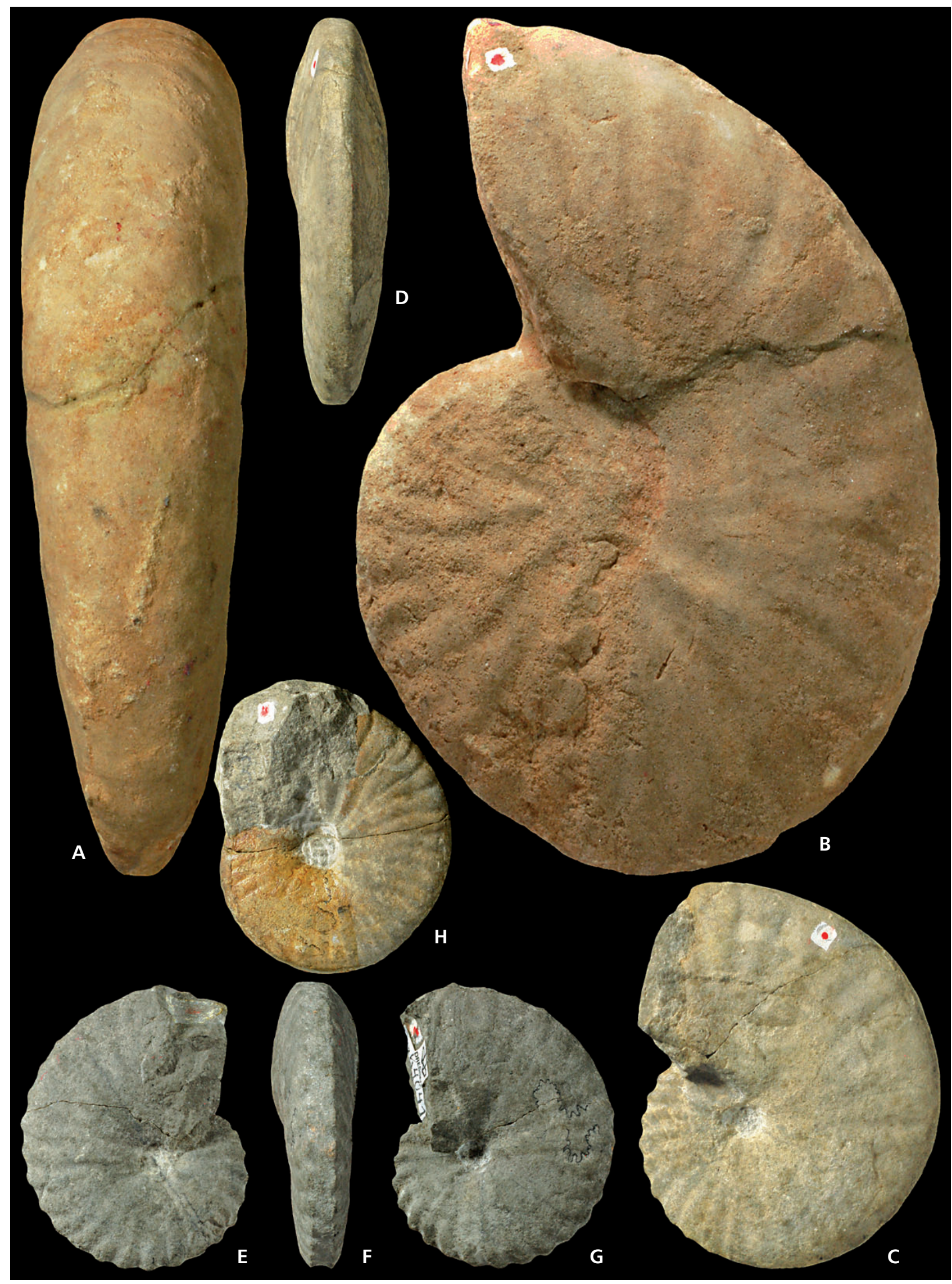


1988 Metoicoceras geslinianum (d'Orbigny, 1850). - Kennedy, p. 58, pl. 9, fig. 8; pl. 11, figs 25-27; pl. 22, figs 16, 17; text-figs 20-23.

1989 Metoicoceras geslinianum (d'Orbigny). - Cobban et al., p. 42, figs 84A-W, AA.

1989 Metoicoceras geslinianum (d'Orbigny, 1850). - Vašíček, p. 73, pl. 6, figs 2, 3 .

1998 Metoicoceras geslinianum (d'Orbigny, 1850). - Kaplan et al., p. 172, pl. 13, figs 19, 20.

1998 Metoicoceras geslinianum (d'Orbigny, 1850). - Lehmann, p. 28, pl. 3, fig. 3.

2003 Metoicoceras geslinianum (d'Orbigny, 1850). - Kennedy et al., p. 11, pl. 3, figs 1-9; pl. 5, figs 4-9.

2005 Metoicoceras geslinianum (d'Orbigny). - Meister \& Abdallah, p. 128, pl. 8, fig. 1 .

2009 Metoicoceras geslinianum (d'Orbigny, 1850). - Lehmann \& Herbig, p. 69, pl. 1, figs T, U.

2010 Metoicoceras geslinianum (d'Orbigny, 1850). Nagm et al., p. 481, figs 7F, 8A-C.

Material. - Five specimens (see measurements) from the Dölzschen Formation in Dresden-Ockerwitz and Dresden-Plauen, and two specimens (SaK640, 641) from the sandy Dölzschen Formation of Welschhufe near Bannewitz. All specimens are from the Upper Cenomanian.

\section{Measurements. -}

Specimen $\quad \mathrm{D} \quad \mathrm{Wb} \quad \mathrm{Wh} \quad \mathrm{Wb} / \mathrm{Wh} \quad \mathrm{U}$

$\begin{array}{llllll}\text { SaK4041 } & 49.8(100) & 15.2(30.5) & 27.5(55.2) & 0.55 & 5.8(11.6)\end{array}$

$\begin{array}{llllll}\mathrm{SaK} 4040 & 70.1(100) & 17.5(24.9) & 40.5(57.7) & 0.43 & 6.5(9.2)\end{array}$

$\begin{array}{llllll}\mathrm{SaK} 4045 & 73.5(100) & 20.0(27.2) & 35.4(48.1) & 0.56 & 12.7(17.2)\end{array}$

$\begin{array}{llllll}\text { SaK5433 } & 92.4(100) & 27.2(29.4) & 46.1(49.8) & 0.59 & 17.2(18.6)\end{array}$

$\begin{array}{llllll}\text { SaK2179 } & 110.0(100) & 15.1(13.7) & 59.7(54.2) & 0.25 & 14.3(13.0)\end{array}$

$\begin{array}{lllllll}\text { SaK640 } & 135.4(100) & 35.2(25.9) & 64.1(47.3) & 0.54 & 28.8(21.2)\end{array}$

$\begin{array}{lllllll}\text { SaK641 } & 160.0(100) & 41.8(26.1) & 69.0(43.1) & 0.60 & 32.8(20.5)\end{array}$

Description. - All investigated specimens are involutely coiled; only the two large specimens have U above $20 \%$. The umbilical wall is low with a rounded shoulder. Whorl sections are compressed (Fig. 13A), with greatest breadth on the inner flanks. The flanks are only weakly convex to flat and converge to a more-or-less sharp ventrolateral shoulder. The venter is narrow and slightly sulcate on early whorls and tends to become wider and weakly rounded during ontogeny. The ornamentation consists of broad primary ribs alternating with one or two short intercalated ribs. The primaries start at weak bullate swellings at the umbilical shoulder while the intercalatories appear on the inner or mid-flanks. All ribs are slightly prorsiradiate and end at the ventrolateral shoulder with a strong clavus on the early whorls, becoming weaker later in ontogeny. The suture line (Fig. 13B) has simple outlines and is characterized by a moderately deep and wide adventive lobe.
Remarks. - Metoicoceras geslinianum shows a considerable morphological variability and this has led some authors to describe several new species that subsequently have been considered as different forms of M. geslinianum (Kennedy \& Juignet 1981, Kennedy et al. 1981, Wright \& Kennedy 1981, Kennedy 1988). Kennedy et al. (1981) have discussed these forms in detail and observed transitional morphologies among many of these varieties. Furthermore, Kennedy (1988) discussed the variability of the well-preserved material described by de Grossouvre (1912) from France as it shows the same wide range of intraspecific variation and dimorphism. Based on the limited material from the Saxonian Cretaceous, we cannot comment on the reported morphological variations. However, all specimens can be safely assigned to M. geslinianum.

Occurrence. - Metoicoceras geslinianum is the index fossil of the middle Late Cenomanian Metoicoceras geslinianum Zone (Kennedy 1984; Wright et al. in Wright \& Kennedy 1984; Hancock 1991) and has records from Europe (Germany, Czech Republic, England, France, Spain), United States (Texas and western interior), Southern America (Mexico, Brazil, Colombia), and Africa (Morocco, Tunisia, Egypt, Nigeria, Angola) (e.g., Kennedy \& Juignet 1981, Wright \& Kennedy 1981).

\section{Genus Spathites Kummel \& Decker, 1954}

Type species. - Spathites chispaensis Kummel \& Decker, 1954, p. 311, pl. 30, figs 1, 2; pl. 31, figs 1-15; text-fig. 1; by original designation.

\section{Subgenus Spathites (Jeanrogericeras) Wiedmann, 1960}

Type species. - Ammonites reveliereanus Courtiller, 1860, p. 249 , pl. 2, figs 5-8; by original designation.

\section{Spathites (Jeanrogericeras) reveliereanus}

(Courtiller, 1860)

Figures $15,16,17 \mathrm{~A}-\mathrm{F}$

*1860 Ammonites reveliereanus; Courtiller, p. 249, pl. 2, figs 5-8.

1867 Ammonites reveliereanus (spec. nov.). - Courtiller, p. 4, pl. 3, figs 1-4.

1902 Mammites binicostatus nov. spec.; Petrascheck, p. 145 , pl. 7, fig. 6a, b; pl. 8, figs 1a, b, 3a, b.

1909 Mammites binicostatus Petrascheck. - Wanderer, p. 64 , pl. 10, fig. 2.

1980 Spathites (Jeanrogericeras) reveliereanus (Courtiller). - Kennedy et al., p. 826, pl. 105, 1-12; pl. 106, figs 1, 2; text-figs 3, 5, 6 (with synonymy). 
1981 Spathites (Jeanrogericeras) reveliereanus (Courtiller, 1860). - Wright \& Kennedy, text-fig. 22.

1992 Spathites (Jeanrogericeras) reveliereanus (Courtiller), 1860. - Thomel, p. 223, pl. 118, figs 3, 4; pl. 119, fig. 1.

2007 Spathites (Jeanrogericeras) reveliereanus (Courtiller, 1860). - Barroso-Barcenilla, p. 138, pl. 4, fig. G; pl. 5, figs A-D; text-figs 6A, B (with additional synonymy).

2009 Spathites (Jeanrogericeras) reveliereanus (Courtiller, 1860). - Lehmann \& Herbig, p. 70, pl. 1, figs C-E.

Material. - In total 40 specimens from the Lower Turonian Brießnitz Formation, 29 specimens from Dresden-Leubnitz and 11 specimens from Dresden-Lockwitz (see Wilmsen et al. 2011 for details on the latter locality). 24 specimens have been measured (see below) while 16 specimens are crushed and not complete (SaK5169, 5218, 5219, 5254, 5257, 5262, 5271, 5274, 5368, 5369, 5371, 5375, 5377, $5383,12104,53233)$.

Measurements. -

(c. = costal, i. $=$ intercostal $)$

Specimen D Wb Wh Wb/Wh U $\begin{array}{llllll}\text { SaK5558 c } & 52.9(100) & 30.2(57.0) & 26.1(49.3) & 1.15 & 0.95(17.9)\end{array}$

$\begin{array}{llllll}\text { SaK5558 i } & 51.0(100) & 23.4(45.8) & 25.3(49.6) & 0.92 & 0.95(18.6)\end{array}$ $\begin{array}{lllllll}\text { SaK5269 c } & 60.5(100) & 31.5(52.0) & 33.1(54.7) & 0.95 & 12.6(20.8)\end{array}$ $\begin{array}{llllll}\text { SaK5269 i } & 57.4(100) & 25.7(44.7) & 30.5(53.1) & 0.84 & 12.6(21.9)\end{array}$ $\begin{array}{lllllll}\text { SaK5261 c } & 70.1(100) & 35.1(50.0) & 33.6(47.9) & 1.04 & 19.4(27.6)\end{array}$ $\begin{array}{llllll}\text { SaK5261 i } & 69.7(100) & 31.7(45.4) & 33.3(47.7) & 0.95 & 19.4(27.8)\end{array}$ $\begin{array}{lllllll}\text { SaK5256 c } & 72.2(100) & 32.4(44.8) & 36.3(50.2) & 0.89 & 15.6(21.6)\end{array}$ $\begin{array}{llllll}\text { SaK5256 i } & 67.4(100) & 27.2(40.3) & 33.9(50.2) & 0.80 & 15.6(23.1)\end{array}$ $\begin{array}{llllll}\text { SaK5253 c } & 84.3(100) & 57.4(68.0) & 41.5(49.2) & 1.38 & 18.2(21.5)\end{array}$ $\begin{array}{llllll}\text { SaK5253 i } & 80.2(100) & 44.0(54.8) & 38.6(48.1) & 1.13 & 18.2(22.6)\end{array}$ SaK12254 c 86.5 (100) $48.2(55.7) \quad 42.5$ (49.1) $1.1321 .1(24.3)$ SaK12254 i $81.1(100) 44.3$ (54.6) 37.9 (46.7) $1.1621 .1(26.0)$ $\begin{array}{llllll}\text { SaK5242 c } & 92.4(100) & 32.6(35.2) & 45.9(49.6) & 0.71 & 22.0(23.8)\end{array}$ $\begin{array}{llllll}\text { SaK5242 i } & 89.6(100) & 28.8(32.1) & 43.2(48.2) & 0.66 & 22.0(24.5)\end{array}$ SaK12276 c 98.4 (100) $60.1(61.0) \quad 45.9$ (46.6) $1.30 \quad 28.1(28.5)$ SaK12276 i $95.1(100) 51.5(54.1) \quad 43.6(45.8) \quad 1.18 \quad 28.1(29.5)$ SaK5178 c 100.7 (100) 43.2 (42.8) $48.6(48.2) \quad 0.88 \quad 35.1(34.8)$ $\begin{array}{llllll}\text { SaK5178 i } & 97.2(100) & 36.0(37.0) & 46.7(48.0) & 0.77 & 35.1(36.1)\end{array}$ SaK12277 c102.3 (100) $56.1(54.8) \quad 46.3$ (45.2) 1.2123 .5 (22.9) SaK12277 i 99.3 (100) $51.4(51.7) \quad 46.0$ (46.3) 1.1123 .5 (23.6) $\begin{array}{llllll}\text { SaK5230 c } 110.1 \text { (100) } 50.0(45.4) & 43.2(39.2) & 1.15 & 37.8(34.3)\end{array}$ $\begin{array}{llllll}\mathrm{SaK} 5230 & \text { i } 105.7(100) & 47.7(45.1) & 43.1(40.7) & 1.10 & 37.8(35.7)\end{array}$ $\begin{array}{llllll}\text { average c } & 84.58 & 43.34 & 40.27 & 1.07 & 21.30\end{array}$ $\begin{array}{llllll}\text { average i } & 81.24 & 37.42 & 38.37 & 0.96 & 21.30\end{array}$ $\begin{array}{llllll}\text { SaK12268 } & 57.1(100) & 27.8(48.6) & 28.0(49.0) & 0.99 & 14.6(25.5)\end{array}$ $\begin{array}{llllll}\text { SaK5276 } & 57.2(100) & 31.8(55.5) & 34.5(60.3) & 0.92 & 10.3(18.0)\end{array}$ $\begin{array}{lllllll}\text { SaK5272 } & 72.3(100) & 44.8(61.9) & 34.9(48.2) & 1.28 & 19.8(27.3)\end{array}$ $\begin{array}{lllllll}\mathrm{SaK} 5380 & 75.2(100) & 46.2(61.4) & 35.9(47.7) & 1.28 & 16.0(21.2)\end{array}$ $\begin{array}{llllll}\text { SaK5179 } & 82.5(100) & 35.9(43.5) & 45.6(55.2) & 0.78 & 18.0(21.8)\end{array}$
$\begin{array}{llllll}\mathrm{SaK} 12205 & 83.9(100) & 27.9(33.2) & 45.5(54.2) & 0.61 & 16.5(19.6)\end{array}$ SaK5264 $91.2(100) 33.5(36.7) \quad 41.4(45.3) \quad 0.80 \quad 21.0(23.0)$ $\begin{array}{lllllll}\text { SaK5252 } & 91.6(100) & 44.8(48.9) & 41.1(44.8) & 1.09 & 20.8(22.7)\end{array}$ $\begin{array}{lllllll}\text { SaK5388 } & 96.9(100) & 31.2(32.1) & 45.4(46.8) & 0.68 & 24.2(24.9)\end{array}$ $\begin{array}{lllllll}\text { SaK5255 } & 98.1(100) & 33.5(34.1) & 45.9(46.7) & 0.72 & 31.5(32.1)\end{array}$ $\begin{array}{llllll}\text { SaK12157 } & 100.7(100) & 31.6(31.1) & 44.3(43.9) & 0.71 & 26.3(26.1)\end{array}$ $\begin{array}{lllllll}\text { SaK12253 } 114.8(100) & 56.3(49.0) & 46.4(40.4) & 1.21 & 36.7(31.9)\end{array}$ $\begin{array}{llllll}\text { SaK12124 } 116.9(100) & 33.6(28.7) & 47.9(40.9) & 0.70 & 35.5(30.3)\end{array}$ $\begin{array}{llllll}\text { average } & 87.65 & 36.83 & 41.29 & 0.82 & 22.40\end{array}$

Description. - Coiling is involute to moderately evolute, with $\mathrm{U}$ representing $<20 \%$ in smaller and $>30 \%$ in larger specimens. Whorl sections are variable (Fig. 15), ranging from depressed in early stages to compressed with trapezoidal section in larger specimens. The umbilicus is deep with subvertical walls, rounded shoulders and bordered by up to eight prominent umbilical tubercles. The flanks are convex in early stages. Later in ontogeny, only the inner flanks are convex and the outer ones are straight and converge towards the narrow and sulcate venter (Fig. 15). The flank ornamentation consists of strong, broad recti- to slightly retroradiate ribs arising in pairs from the umbilical tubercles. Intercalatories starting at mid-flank may also be developed. Each rib bears faint inner and well-developed outer tubercles at the ventrolateral shoulders. Sutures are not preserved.

Remarks. - Some of the investigated material has already been studied by Petrascheck (1902). Based on these specimens, he erected Mammites binicostatus as a new species. Wiedmann (1960, 1964) distinguished it from Spathites (Jeanrogericeras) reveliereanus on the basis of the absence of intercalated ribs, eight rather than four umbilical tubercles, sharper ventrolateral shoulder, sulcate venter, larger umbilicus and less asymmetric lobes of the suture line. Kennedy et al. (1980) argued that none of these criteria discussed by Wiedmann are sufficient to justify a separation of the two taxa, especially in the view of the fact that the lectotype of $S$. reveliereanus has at least seven umbilical tubercles, and other specimens have eight or nine. In addition, the sharp ventrolateral shoulder is a matter of preservation (lateral compaction). Recently, Barroso-Barcenilla (2007) described both, S. reveliereanus and M. binicostatus, from time-equivalent Lower Turonian strata in Spain and likewise considered Petrascheck's taxon as a synonym of Courtiller's species. Starting from Courtiller (1860), many papers discussed the considerable intraspecific variation in $S$. (J.) reveliereanus and, therefore, some authors (e.g., Karrenberg 1935) used different forms within the species to accommodate this variability. However, a comparison of the biometric data presented above (using costal and inter-costal measurements separately) show that there is a very good correlation of $\mathrm{D}$ and $\mathrm{U}(\mathrm{r}=0.92, \mathrm{n}=24)$ as well as $\mathrm{D}$ and $\mathrm{Wh}(\mathrm{r}=\sim 0.90)$, while $\mathrm{D}$ and $\mathrm{Wb}$ are less 


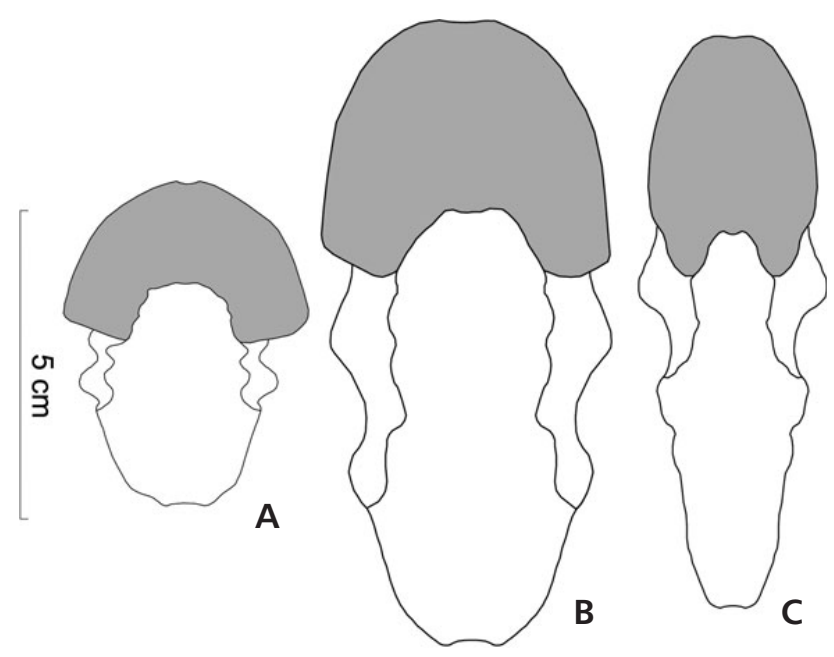

Figure 15. Whorl sections of Spathites (Jeanrogericeras) reveliereanus (Courtiller, 1860). • A - MMG: SaK5558, B - MMG: SaK5230, C - MMG: SaK5242. Lower Turonian Brießnitz Formation, DresdenLeubnitz.

well correlated $(r=0.28-0.78)$. Due to the predominant bedding-parallel (= sub-horizontal) burial of ammonite shells, Wb and flank ornament (tubercles, ribs) are much more prone to alteration by compaction compared to the other parameters such as Wh and U. Thus, taphonomic processes may explain much of the inferred intraspecific variability observed in S. reveliereanus. Differences between the species related to the genus and subgenus have been carefully discussed for example by Kennedy et al. (1980), Barroso-Barcenilla (2007) and Lehmann \& Herbig (2009).

Occurrence. $-S$. (J.) reveliereanus occurs in the Early Turonian Mammites nodosoides Zone and the Middle Turonian Collignoniceras woollgari Zone of Germany, Spain, France, Romania, India and Morocco (see Barroso-Barcenilla 2007 and Lehmann \& Herbig 2009 for further details).

\section{Genus Mammites Laube \& Bruder, 1887}

Type species. - Ammonites nodosoides Schlüter, 1871, p. 19, pl. 8, figs 1-4; by monotypy.

\section{Mammites nodosoides (Schlüter, 1871)}

Figures 17G-H, 18A-B

*1871 Ammonites nodosoides; Schlüter, p. 19, pl. 8, figs $1-4$.
1902 Mammites michelobensis Laube u. Bruder. - Petrascheck, p. 142, pl. 8, fig. 2; pl. 9, fig. 2; pl. 10, fig. 1.

1909 Mammites michelobensis Laube u. Bruder. - Wanderer, p. 63, pl. 10, fig. 1.

1981 Mammites nodosoides (Schlüter, 1871). - Wright \& Kennedy, p. 75, pl. 17, fig. 3; pl. 19, fig. 3; pl. 20, fig. 4; pl. 22, fig. 4; pl. 23, figs 1?, 2, 3; pl. 24, figs 2, 3; text-figs 19B, 23, 24 (with full synonymy).

2009 Mammites nodosoides (Schlüter, 1871). - Lehmann \& Herbig, p. 71, pl. 1, figs J, K, R, S.

Remarks. - A large number (more than 150 specimens) of this important Early Turonian index species has been collected from the study area. A systematic description of the species, with complete discussion of its taxonomic problems as well as biometric, biostratigraphic and palaeobiogeographic remarks will be given in a separate paper (Nagm, in prep.). There seem to be two basic morphotypes, i.e., a small, strongly ornamented and involute form (Fig. 17G, H) and a larger, more evolute and less strongly ornamented form (Fig. 18A, B). The same forms can be recognized in the two paralectotypes illustrated by Schlüter (1971, pl. 8, figs 1-4). Specimen SaK5200 has already been figured by Petrascheck (1902, pl. 10, fig. 1).

Occurrence. - Mammites nodosoides is the index species of the eponymous upper Lower Turonian standard ammonite zone (Kennedy 1986, Hancock 1991). It occurs in a variety of European countries, northern Africa, Madagascar, the Middle East as well as North and South America (Wright \& Kennedy 1981).

Superfamily Turrilitoidea Gill, 1871

Family Baculitidae Gill, 1871

\section{Genus Sciponoceras Hyatt, 1894}

Type species. - Hamites baculoide Mantell, 1822, p. 123, pl. 23, figs 6,7 ; by original designation.

\section{Sciponoceras gracile (Shumard, 1860)}

Figure 18C, D

*1860 Baculites gracilis; Shumard, p. 596.

1875 Baculites subbaculoides; Gein., p. 281, pl. 63, fig. 1.

Figure 16. Spathites (Jeanrogericeras) reveliereanus (Courtiller, 1860). • A - lateral view, B - ventral view, C - apertural view. MMG: SaK5230. Lower Turonian Brießnitz Formation, Dresden-Leubnitz. • D - lateral view, E - ventral view. MMG: SaK5256. Lower Turonian Brießnitz Formation, Dresden-Leubnitz. • F, G - lateral views, H - ventral view. MMG: SaK5558 (original of Petrascheck 1902, pl. 7, fig. 6). Lower Turonian Brießnitz Formation, Dresden-Leubnitz. $\times 1$. 


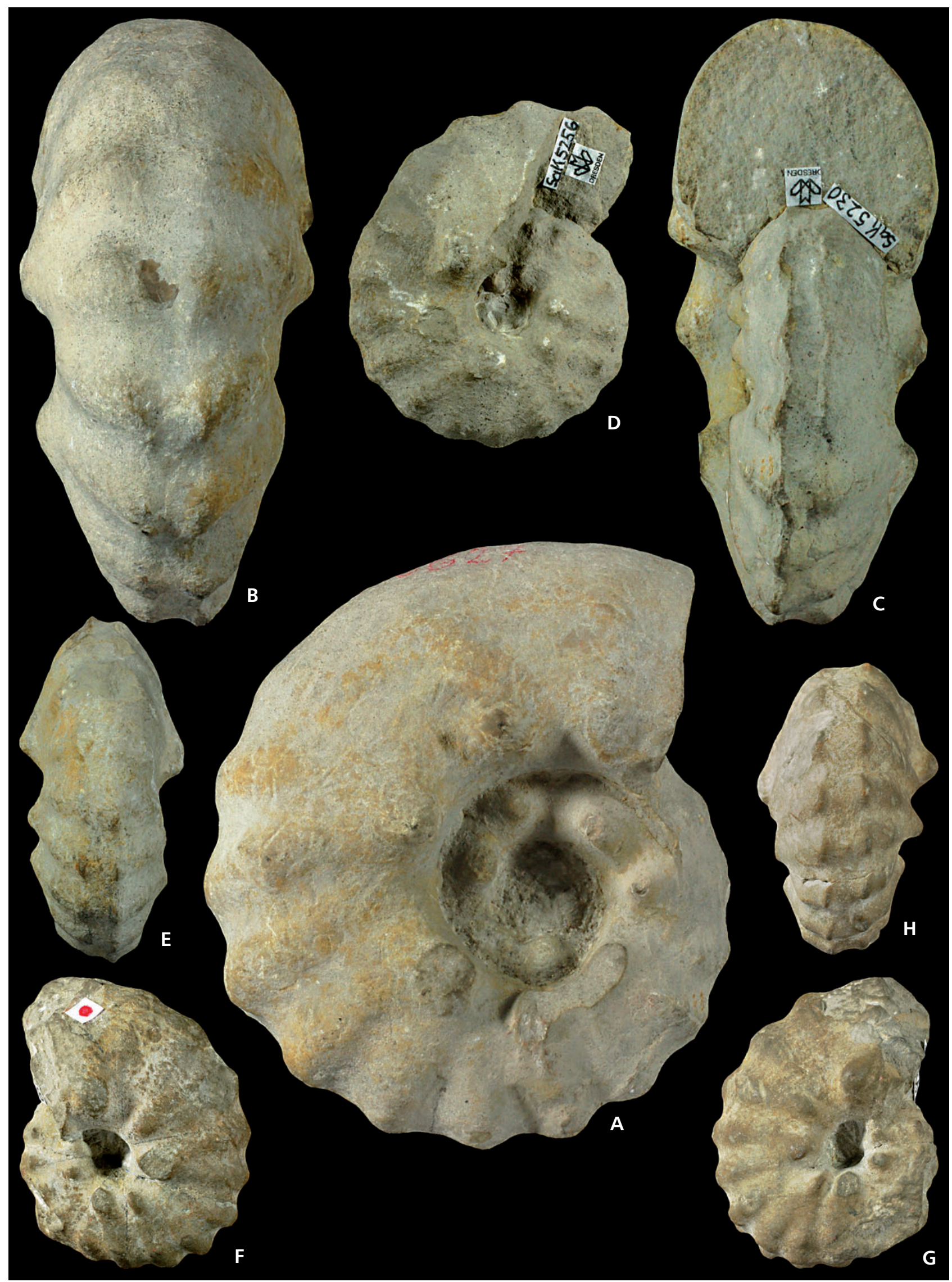


1972 Sciponoceras gracile (Shumard). - Cobban \& Scott, p. 47, pl. 17, figs 9-29; text-fig. 18.

1981 Sciponoceras gracile (Shumard, 1860). - Wright \& Kennedy, p. 112, pl. 31, figs 1-3; pl. 32, figs 8, 11; text-figs 38A-Q.

1988 Sciponoceras gracile (Shumard, 1860). - Kennedy, p. 108, pl. 20, figs 1-14, 17-20; text-fig. 38 .

1989 Sciponoceras gracile (Shumard). - Cobban et al., p. 61 , fig. $96 \mathrm{D}$

2003 Sciponoceras gracile (Shumard, 1860). - Kennedy et al., p. 14, pl. 6, figs 1-19.

Material. - Two specimens (SaK4645, 4708) from the Upper Cenomanian Dölzschen Formation in Rippien near Bannewitz and Oberau near Meißen.

Description. - Very slender baculitid with oval to subcircular, slightly compressed whorl section. Ornamentation consists of feeble prorsiradiate and regularly spaced ribs on the inner flanks that strengthen on the outer flank and cross the venter in a broad convexity. Sutures are not preserved.

Remarks. - Cobban \& Scott (1972) redescribed Sciponoceras gracile and have provided a fundamental account of the species. The studied specimens have been identified by Geinitz (1875) as Baculites subbaculoides. Wright \& Kennedy (1981) considered the figured specimens of Geinitz as typical $S$. gracile, and we agree in this respect. In addition, Wright \& Kennedy (1981) have discussed the differences between $S$. gracile and other species of the genus ( $S$. baculoides, S. bohemicum, S. glaessneri and S. kossmati).

Occurrence. - Sciponoceras gracile occurs in the Late Cenomanian Metoicoceras geslinianum Zone of Germany, England, France, United States (Texas, Arizona, New Mexico, Colorado, Kansas, Wyoming, Montana, Utah, California), Mexico, and possibly Angola (Wright \& Kennedy 1981).

Superfamily Scaphitoidea Gill, 1871

Family Scaphitidae Gill, 1871

Subfamily Scaphitinae Gill, 1871

\section{Genus Scaphites Parkinson, 1811}

Type species. - Scaphites equalis Sowerby, 1813, p. 53, pl. 18, figs 1-3; by the subsequent designation of Meek (1876, p. 413).

\section{Scaphites equalis Sowerby, 1813 \\ Figures 18E-G}

*1813 Scaphites equalis; Sowerby, p. 53, pl. 18, figs 1-3.

1975 Scaphites obliquus Brongniart. - Geinitz, p. 280.

1872 Scaphites aequalis Sow. - Fritsch, p. 41, pl. 13, fig. 6.

1996 Scaphites equalis J. Sowerby, 1813. - Wright \& Kennedy, p. 394, pl. 116, figs 1-5, 7-11; pl. 117, figs $1-11$; pl. 118, figs $1-13$; text-figs $154 C$, D (with full synonymy).

Material. - Two specimens (SaK1408, 2175) from the Dölzschen Formation of the Plauen'scher Grund (Ratssteinbruch) in Dresden-Plauen as well as an additional specimen (MF_Sak214) from the same locality and stratigraphic level of the private collection of Markus Fengler (Dresden). This specimen will be transferred into the MMG collection at a later date.

Description. - The specimens are characterized by slightly depressed whorl sections and small and deep umbilici. Venters are broadly rounded with short, arched flanks. Both flanks carry distant, short and shallow primaries that start at mid-flank and end at the ventrolateral shoulder with distinct tubercles. Between these tubercles, fine densely spaced single or double ribs cross the venter, some arise at the tubercles. Sutures are not preserved.

Remarks. - The studied specimens can be included in S. equalis without any doubt as they closely match the description and illustrations given in the revision of Cenomanian Scaphitidae by Wright \& Kennedy (1996). The antecedents of Scaphites equalis and differences between it and Scaphites obliquus the have also been thoroughly discussed by Wright \& Kennedy (1996). They also noted the great intraspecific variation in Scaphites equalis (size, compression and inflation, strength and number of secondary ribs on the venter of the shaft). The occurrence of scaphitids from the Dölzschen Formation at DresdenPlauen has already been noted by Geinitz (1875) and Tröger (1956), but this is the first properly documented record of $S$. equalis. The record of $S$. equalis by Geinitz, (1846, p. 301, pl. 12, fig. 1) from the lower Upper Turonian Strehlen Limestone of the Strehlen Formation is probably related to $S$. geinitzi d'Orbigny.

Occurrence. - Scaphites equalis occurs in the Middle and Upper Cenomanian of England, Germany, France, Czech

Figure 17. A-F - Spathites (Jeanrogericeras) reveliereanus (Courtiller, 1860). • A - apertural view, B - lateral view, C - ventral view. MMG: SaK5242 (original of Petrascheck 1902, pl. 8, fig. 3). Lower Turonian Brießnitz Formation, Dresden-Leubnitz. $\times 1$. $\bullet$ D - apertural view, E - lateral view, F - ventral view. MMG: SaK12254. Lower Turonian Brießnitz Formation, Dresden-Lockwitz. × 1. • G, H - Mammites nodosoides (Schlüter, 1871). G - lateral view, H - apertural view. MMG: SaK5240. Lower Turonian Brießnitz Formation, Dresden-Leubnitz. $\times 1$. 


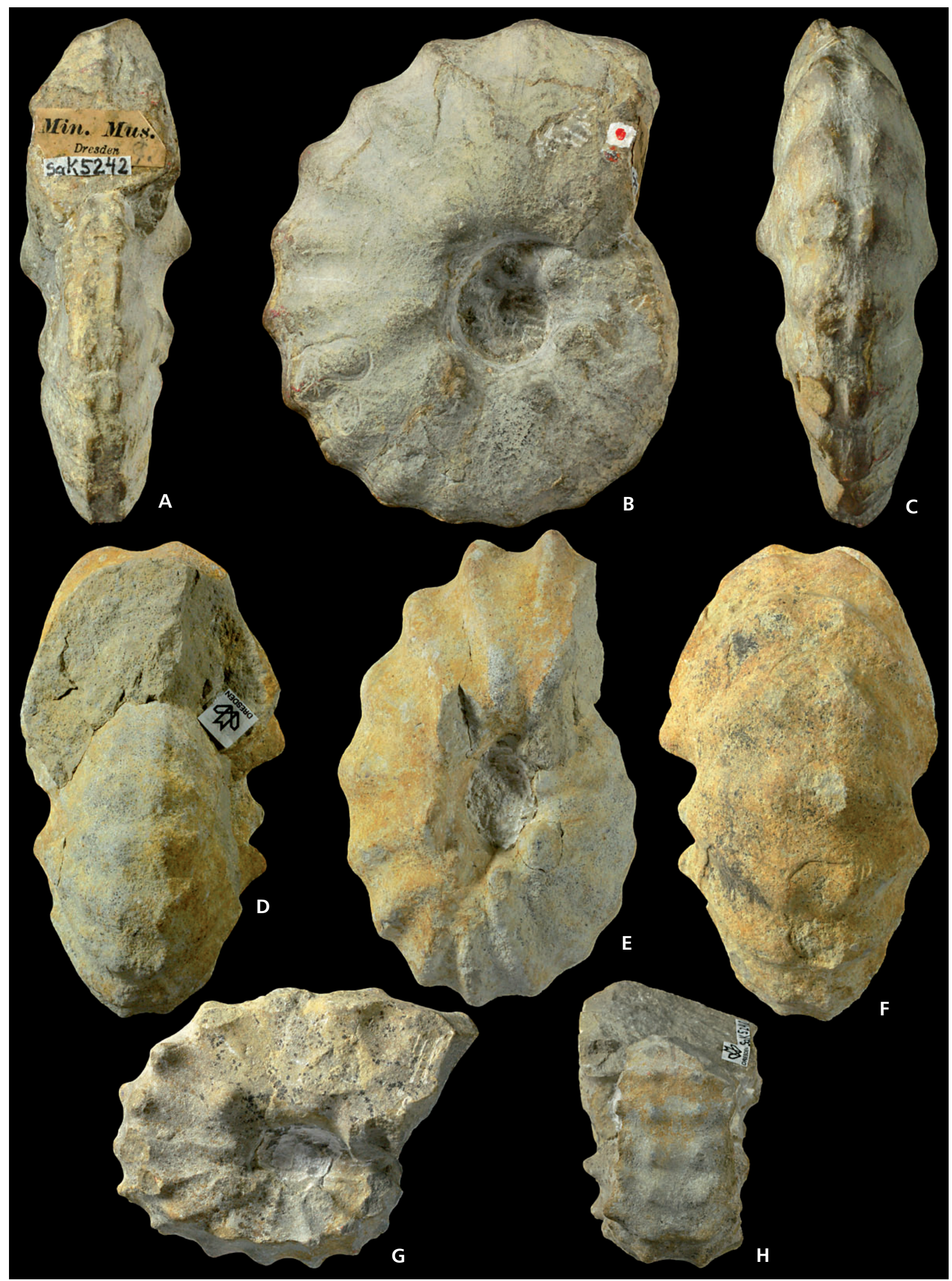




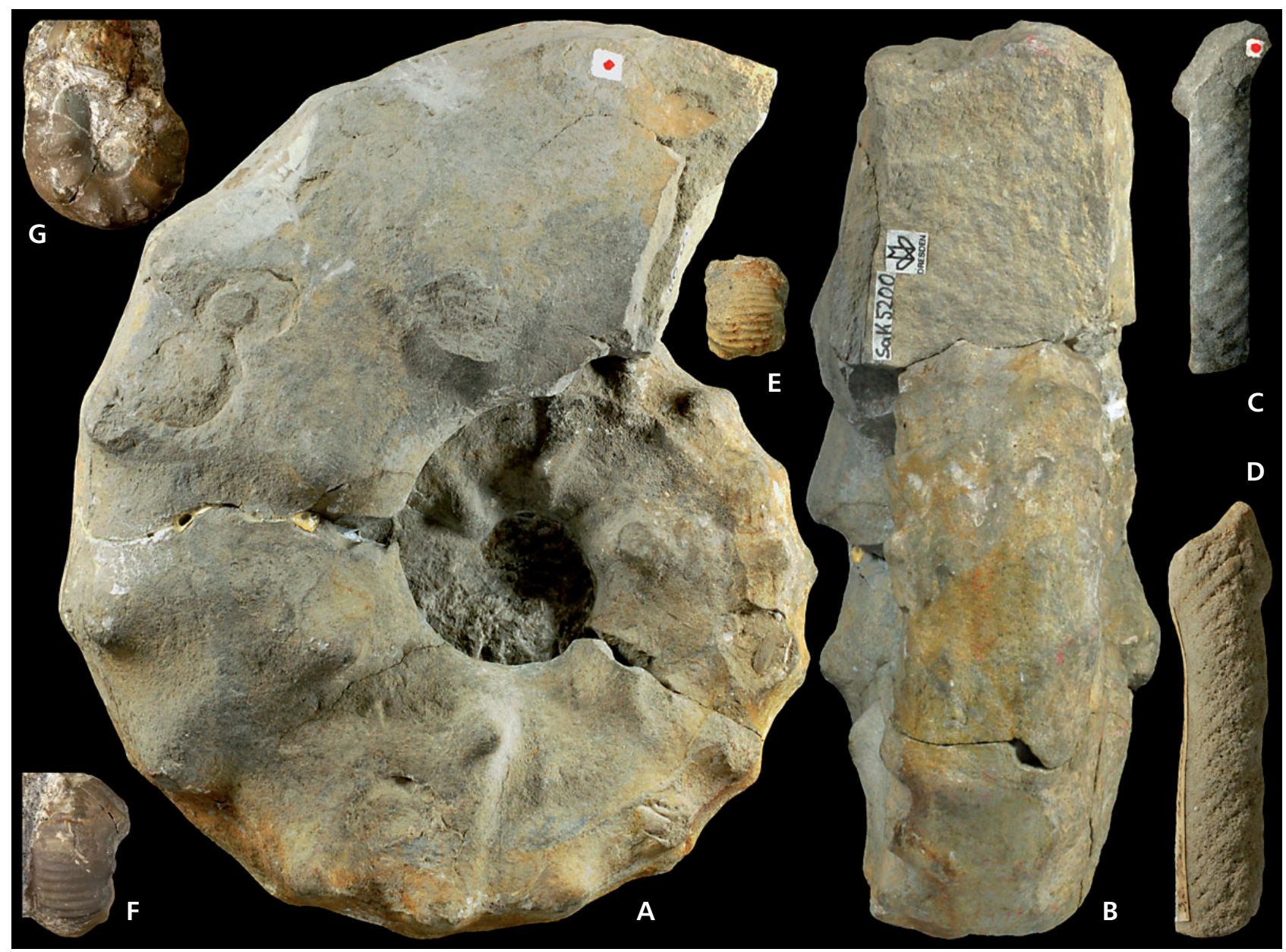

Figure 18. A, B - Mammites nodosoides (Schlüter, 1871). A - lateral view, B - apertural view. MMG: SaK5200 (original of Petrascheck 1902, pl. 10, fig. 1). Lower Turonian Brießnitz Formation, Dresden-Leubnitz. $\times 1 . \bullet C, D-$ Sciponoceras gracile (Shumard, 1860), flanks views. C - MMG: SaK4708 (original of Geinitz 1875, pl. 63, fig. 1), Upper Cenomanian Dölzschen Formation, Oberau near Meißen, D - MMG: SaK4645. Upper Cenomanian Dölzschen Formation, Rippien near Bannewitz (south of Dresden). × 1. E E, F, G - Scaphites equalis Sowerby; E - ventral view. MMG: SaK2175, F- ventral view, G-lateral view. M. Fengler collection: SaK214. Upper Cenomanian Dölzschen Formation, Plauen'scher Grund in Dresden-Plauen. $\times 1$.

Republic, Poland, Ukraine, the Caucasus, Turkmenia, Iran, Algeria, Tunisia and southern India (Wright \& Kennedy 1996).

\section{Concluding remarks}

The Upper Cenomanian to Lower Turonian ammonoid fauna of the Saxonian Cretaceous (Elbtal Group) has been revised based on the study of 270 specimens hosted in the collection of the Museum für Mineralogie und Geologie of the Senckenberg Naturhistorische Sammlungen Dresden (Germany). Several of the specimens are historical originals that have already been treated and illustrated in the monographic works of Geinitz (1839-1843, 1849, 1871-1875, 1872-1875), Petrascheck (1902) and Wanderer (1909). However, these important works date back over a century and numerous taxonomic modifications have been necessary. In total, 12 species have been recognized and, based on this revision, a number of ammonoids are now reported and/or illustrated for the first time from the Elbtal Group: Euomphaloceras septemseriatum, Neocardioceras juddii barroisi, Watinoceras coloradoense, Spathites (Jeanrogericeras) reveliereanus, Sciponoceras gracile and Scaphites equalis. The study demonstrated the presence of all Upper Cenomanian and Lower Turonian standard ammonite biozones ( $c f$. Kennedy 1984, 1986; Wright et al. in Wright \& Kennedy 1984; Hancock 1991) for the lithostratigraphic succession of the lower Elbtal Group: the lower Upper Cenomanian Calycoceras naviculare Zone, represented by the Oberhäslich Formation, the mid- and upper Upper Cenomanian Metoicoceras geslinianum and Neocardioceras juddii zones, represented by the Dölzschen Formation, and the Lower Turonian Watinoceras coloradoense and Mammites nodosoides zones, represented by the Brießnitz Formation of the Dresden area 
(in the Elbsandsteingebirge, these zones are represented by the Schmilka Formation).

Concerning taxonomical corrections, the most important changes relate to $N$. juddii barroisi from the Dölzschen Formation of Dresden-Plauen, which has been identified as Ammonites neptuni Gein. by Geinitz (1872-1875; Subprionocyclus neptuni is the index of the lower Upper Turonian) and W. coloradoense which has been identified as Schlönbachia [sic] gracillima Kossmat by Petrascheck (1902). Furthermore, Mammites binicostatus Petrascheck, 1902, a species name widely used in Saxony, is a subjective junior synonym of Spathites $(J$.$) reveliereanus$ (Courtiller, 1860), as already suggested by Kennedy et al. (1980).

In comparison to contemporaneous faunas from Egypt (Nagm et al. 2010, Nagm \& Wilmsen 2012), the ammonoids from the Saxonian Cretaceous are strongly ornamented and mainly related to widely distributed Acanthoceratidae. The strongly Tethyan-influenced Upper Cenomanian-Lower Turonian ammonites of Egypt are predominatly smooth-shelled forms with a dominance of Vascoceratidae. Species that occur in both areas are rare, only represented by the Late Cenomanian Euomphaloceras septemseriatum and Metoicoceras geslinianum (d'Orbigny, 1850). During the Early Turonian, the ammonite faunas are completely different with a predominance of Pseudotissotiinae in Egypt and Mammitinae in Saxony. This observation is in accord with increasing biogeographic differentiation at that time reported from many regions in the world (e.g., Wiedmann 1988, Lehmann \& Herbig 2009).

\section{Acknowledgements}

We are indebted to R. Hoffmann (Bochum) and Z. Vašíček (Ostrava) for constructive reviews as well as Š. Doležalová (Prague) for the professional editorial handling. Furthermore, we express gratitude to W.J. Kennedy (Oxford) for the discussion of some taxonomic problems. Thanks also to $\mathrm{R}$. Winkler (Senckenberg Dresden) for his photographic work and M. Fengler (Dresden) for the loan of S. equalis. The financial support of the German Academic Exchange Service (DAAD) for the stay of Emad Nagm in Germany is greatly acknowledgement. This paper is also a contribution to project WI 1743/6-1 granted to MW by the German Research Foundation (DFG).

\section{References}

BARrois, C. \& Guerne, J. DE 1878. Description de quelques espèces nouvelles de la craie de l'est du bassin de Paris. Annales de la Société Géologique du Nord 5, 42-64.

Barroso-Barcenilla, F. 2004. Acanthoceratidae and ammonite zonation of the upper Cenomanian and the lower Turonian in the Puentedey area, Basque-Cantabrian Basin, Spain. Coloquios de Paleontología 54, 83-114.

Barroso-Barcenilla, F. 2007. Revision and new data of the ammonite family Acanthoceratidae de Grossouvre, 1894, from the Lower Turonian of the Iberian Trough, Spain. Palaeontographica, Abteilung A 280, 123-163.

Bengtson, P. 1988. Open nomenclature. Palaeontology 31, 223-227.

Chancellor, G.R. 1982. Cenomanian-Turonian ammonites from Coahuila, Mexico. Bulletin of the Geological Institution of the University of Uppsala 9, 77-129.

Chancellor, G.R., Kennedy, W.J. \& Hancock, J.M. 1994. Turonian ammonites faunas from central Tunisia. Special $\mathrm{Pa}$ pers in Palaeontology 50, 1-188.

ChrZAstek, A. 2012. Palaeontology of the Middle Turonian limestones of the Nysa Kłodzka Graben (Sudetes, SW Poland): biostratigraphical and palaeogeographical implications. Geologos 18(2), 83-109. DOI 10.2478/v10118-012-0007-z

Cobban, W.A. \& ScotT, G.R. 1972. Stratigraphy and ammonite fauna of the Graneros Shale and Greenhorn Limestone near Pueblo, Colorado. U.S. Geological Survey Professional Paper 645, 1-108.

CobBan, W.A. 1988. The Upper Cretaceous ammonite Watinoceras Warren in the Western Interior of the United States. U.S. Geological Survey Bulletin 1788, 1-15.

Cobban, W.A., Hook, S.C. \& KenNedy, W.J. 1989. Upper Cretaceous rocks and ammonite faunas of southwestern New Mexico. New Mexico Bureau of Mines and Mineral Resources Memoir 45, 1-137.

Cooper, M.R. 1978. Uppermost Cenomanian-basal Turonian ammonites from Salinas, Angola. Annals of the South Africa Museum 75, 51-152.

Courtiller, M.A. 1860. Description de trois nouvelles espèces d'ammonites du terrain crétacé. Mémoire de la Société impériale d'Agriculture, Science et des Arts d'Angers 3, 246-252.

Courtiller, M.A. 1867. Les Ammonites du Tuffeau. Annales de la Société Linnéenne du Département de Maine-et-Loire 9, 1-8.

Cragin, F.W. 1893. A contribution to the invertebrate paleontology of the Texas Cretaceous. Texas Geological Survey, $4^{\text {th }} \mathrm{An}$ nual Report (1892), 139-246.

DEKAY, J.E. 1828. Report on several multilocular shells from the state of Delaware, with observations on a second specimen of the new fossil genus Eurypterus. Annals of the Lyceum of Natural History of New York 2, 273-279.

DieTZE, H., 1960. Paläontologische und stratigraphische Untersuchungen der Klippenfazies von Oberau und Meißen (Sächsische Oberkreide). Jahrbuch des Staatlichen Museums für Mineralogie und Geologie Dresden 1960, 1-74.

FRITSCH, A. 1872. Cephalopoden der böhmischen Kreideformation. 52 pp. Verlag des Verfassers, Prag.

Gale, A.S., Bengtson, P. \& Kennedy, W.J. 2005. Ammonites at the Cenomanian-Turonian boundary in the Sergipe basin, Brazil. Bulletin of the Geological Society of Denmark 52, 167-191.

GeINITZ, H.B. 1839-1843. Charakteristik der Schichten und Petrefakten des sächsisch-böhmischen Kreidegebirges sowie der Versteinerungen von Kieslingswalda. 116 pp. (Heft 1-3), 19 pp. (Heft 4). Arnold, Leipzig.

GeINITZ, H.B. 1846. Grundriss der Versteinerungskunde. i-viii, 813 pp. Arnoldische Buchhandlung, Dresden \& Leipzig. 
GEINITZ, H.B. 1849. Das Quadersandsteingebirge oder das Kreidegebirge in Deutschland. 293 pp. Craz \& Gerlach, Freiberg.

GeINITZ, H.B. 1871-1875. Das Elbthalgebirge in Sachsen. Teil I (Der untere Quader). Palaeontographica (Beiträge zur Naturgeschichte der Vorwelt) 20(1), 1-319.

GEINITZ, H.B. 1872-1875. Das Elbthalgebirge in Sachsen. Teil II. Der mittlere und obere Quader. Palaeontographica 20(2), $1-245$.

GiLL, T. 1871. Arrangement of the Families of Mollusks. Smithsonian Miscellaneous Collections 227, i-xvi, 1-49.

Grossouvre, A. DE 1894. Recherches sur la craie supérieure, 2, Paléontologic. Les ammonites de la craie supérieure. Mémoires du Service de la Carte géologique de France, $1-264$.

Grossouvre, A. DE 1912. Le Crétacé de la Loire-Inférieure et de la Vendée. Bulletin de la Société des sciences naturelles de l'Ouest de la France, Nantes (3)2, 1-38.

Hancock, J.M. 1991. Ammonite scales for the Cretaceous system. Cretaceous Research 12, 259-191. DOI 10.1016/0195-6671(91)90037-D

Henderson, J. 1908. New species of Cretaceous invertebrates from northern Colorado. Proceedings of the U.S. National Museum of Natural History 34(1611), 259-264.

HoušA, V. 1967. Lewesiceras Spath (Pachydiscidae, Ammonoidea) from the Turonian of Bohemia. Sbornik geologických věd, Paleontologie 9, 1-50.

Howarth, M.K. 1985. Cenomanian and Turonian ammonites from the Novo Redondo area, Angola. Bulletin of the British Museum of Natural History (Geology) 39, 73-105.

Hyatt, A. 1894. Phylogeny of an acquired characteristic. Proceedings of the American Philosophical Society 32, 349-647.

Hyatt, A. 1900. Cephalopoda, 502-604. In Zittel, K.A. von (1896-1900) Textbook of Palaeontology (translation Eastman, C.R.). Macmillan, London \& New York.

Hyatт, A. 1903. Pseudoceratites of the Cretaceous. United States Geological Survey Monograph 44, 1-351.

Ifrim, C. \& Stinnesbeck, W. 2007. Early Turonian ammonites from Vallecillo, north-eastern Mexico: taxonomy, biostratigraphy and palaeobiogeographic significance. Cretaceous Research 28, 642-664. DOI 10.1016/j.cretres.2006.10.004

Kaplan, U., Kennedy, W.J., Lehmann, J. \& Marcinowski, R. 1998. Stratigraphie und Ammonitenfaunen des westfälischen Cenoman. Geologie und Paläontologie in Westfalen 51, $1-236$.

KarrenberG, H. 1935. Ammonitenfauna der nordspanischen Oberkreide. Palaeontographica, Abteilung A 82, 125-161.

Kennedy, W.J. 1971. Cenomanian ammonites from southern England. Special Papers in Palaeontology 8, 1-133.

KENNEDY, W.J. 1984. Ammonite faunas and the "standard zones" of the Cenomanian to Maastrichtian Stages in their type areas, with some proposals for the definition of the stage boundaries by ammonites. Bulletin of the Geological Society of Denmark 33, 147-161.

KenNEDy, W.J. 1986. Ammonite biostratigraphy of the Albian to basal Santonian. Physics and Chemistry of the Earth 16, $129-182$.

Kennedy, W.J. 1988. Late Cenomanian and Turonian ammonite faunas from north-east and central Texas. Special Papers in Palaeontology 39, 1-131.
Kennedy, W.J. \& Juignet, P. 1981. Upper Cenomanian ammonites from the Environs of Saumur, and the provenance of the types of Ammonites vibrayeanus and Ammonites geslinianus. Cretaceous Research 2, 19-49.

DOI 10.1016/S0195-6671(81)80003-1

Kennedy, W.J. \& Juignet, P. 1984. A revision of the ammonite faunas of the type Cenomanian. 2. The Families Binneyitidae, Desmoceratidae, Engonoceratidae, Placenticeratidae, Hoplitidae, Schloenbachiidae, Lyelliceratidae and Forbesiceratidae. Cretaceous Research 5, 93-161.

DOI 10.1016/S0195-6671(84)80017-8

Kennedy, W.J., Wright, C.W. \& Hancock, J.M. 1980. Origin, evolution, and systematics of the Cretaceous ammonite Spathites. Palaeontology 23, 821-837.

Kennedy, W.J., Juignet, P. \& Hancock, J.M. 1981. Upper Cenomanian ammonites from Anjou and the Vendée, western France. Palaeontology 24, 25-84.

Kennedy, W.J., Juignet, P. \& GiRARd, J. 2003. Uppermost Cenomanian ammonites from Eure, Haute-Normandie, northwest France. Acta Geologica Polonica 53, 1-18.

KLEY, J. \& VoIGT, T. 2008. Late Cretaceous intraplate thrusting in central Europe: Effect of Africa-Iberia-Europe convergence, not Alpine collision. Geology 36, 839-842. DOI 10.1130/G24930A.1

KöHLER, S. 2001. Turrilites-Nachweis aus dem Untercenoman von Meißen. Fossilien 3(1), 163-164.

KoneČnÝ, J. \& VAšíčEK, Z. 1983. Lower Turonian ammonites from the Prokop opencast mine in Březina (E-Bohemia). Časopis pro mineralogii a geologii 28(2), 169-180.

KoneČnÝ, J. \& VAšíčEK, Z. 1987. Die Cephalopoden der Cenoman/Turon-Grenze des Steinbruchs Prokop, Březina bei Moravská Třebová. Acta Musei Moraviae, Scientiae naturales 72, 81-96.

Korn, D., Ebbighausen, V., Bockwinkel, J. \& Klug, C. 2003. The A-mode sutural ontogeny in prolecanitid ammonites. Palaeontology 46, 1123-1132. DOI 10.1046/j.0031-0239.2003.00336.x

Kullman, J. \& Wiedmann, J. 1970. Significance of sutures in phylogeny of Ammonoidea. Paleontological contributions, University of Kansas 44, 1-32.

Kummel, B. \& Decker, J.M. 1954. Lower Turonian ammonites from Texas and Mexico. Journal od Paleontology 28, 310-319.

Laube, G.C. \& Bruder, G. 1887. Ammoniten der böhmischen Kreide. Palaeontographica 33, 217-239.

Lehmann, J. \& Herbig, H.-G. 2009. Late Cretaceous ammonites from the Bou Angueur syncline (Middle Atlas, Morocco) stratigraphic and palaeobiogeographic implications. Palaeontographica A 289, 45-87.

Lehmann, J. 1998. Systematic palaeontology of the ammonites of the Cenomanian-Lower Turonian (Upper Cretaceous) of northern Westphalia, north Germany. Tübinger Geowissenschaftliche Arbeiten Reihe A 37, 1-57.

Mantell, G.A. 1822. The fossils of the South Downs, or Illustrations of the geology of Sussex. 328 pp. Lupton Relfe, London.

Meek, P.B. 1876. A report on the invertebrate Cretaceous and Tertiary fossils of the upper Missouri country, 1-629. In HAYDEN, F.V. Report of the United States Geological Survey of the Territories 9. U.S. Government Printing Office, Washington.

Meister, C. \& Abdallah, H. 2005. Précision sur les successions d'ammonites du Cénomanian-Turonien dans la région de 
Gafsa, Tunisie du centre-sud. Revue de Paléobiologie 24, 111-199.

Mitchell, A.J., UličnÝ, D., Hampson, G.J., Allison, P.A., GoRman, G.J., Piggott, M.D., Wells, M.R. \& Pain, C.C. 2010. Modelling tidal current-induced bed shear stress and palaeocirculation in an epicontinental seaway: the Bohemian Cretaceous Basin, Central Europe. Sedimentology 57, 359-388. DOI 10.1111/j.1365-3091.2009.01082.x

Nagm, E. \& Wilmsen, M. 2012. Upper Cenomanian-Turonian (Cretaceous) ammonoids from Wadi Qena, central Eastern Desert, Egypt: taxonomy, biostratigraphy and palaeobiogeographic implications. Acta Geologica Polonica 62, 63-89.

Nagm, E., Wilmsen, M., Aly, M.F. \& Hewaidy, A. 2010. Upper Cenomanian-Turonian (Upper Cretaceous) ammonoids from the western Wadi Araba, Eastern Desert, Egypt. Cretaceous Research 31, 473-499. DOI 10.1016/j.cretres.2010.05.008

Niebuhr, B., Hiss, M., Kaplan, U., Tröger, K.-A., Voigt, S., Voigt, T., Wiese, F. \& WiLmsen, M. 2007. Lithostratigraphie der norddeutschen Oberkreide. Schriftenreihe der Deutschen Gesellschaft für Geowissenschaften 55, 1-136.

Niebuhr, B., Wilmsen, M., Chellouche, P., Richardt, N. \& PÜRNER, T. 2011. Stratigraphy and facies of the Turonian (Upper Cretaceous) Roding Formation at the southwestern margin of the Bohemian Massif (southern Germany, Bavaria). Zeitschrift der Deutschen Gesellschaft für Geowissenschaften 162(3), 295-316. DOI 10.1127/1860-1804/2011/0162-0295

OGG, J.G. \& Hinnov, L.A. 2012. Cretaceous, 793-853. In GraDSteIn, F.M., OGG, J.G., Schmitz, M. \& OGG, G.M. (eds) The geologic time scale 2012, Volume 2. Elsevier, Amsterdam.

Orbigny, A. D' 1840-1842. Paléontologie Française. Terrain Crétacé I, Céphalopodes. 662 pp. (1-120: 1840; 121-430: 1841; 431-662: 1842). Masson, Paris.

Orbigny, A. D' 1850. Prodrome de Paléontologie stratigraphique universelle des animaux Mollusques et rayonnés faisant suite au cours élémentaire de Paléontologie et de Géologie stratigraphiques 2. 427 pp. Masson, Paris. DOI 10.5962/bhl.title.62810

Parkinson, J. 1811. The fossil Starfish, Echini, Shells, Insects, Amphibia, Mammalia and c. The Organic remains of a Former World 3, 1-479.

Petrascheck, W. 1902. Die Ammoniten der sächsischen Kreideformation. Beiträge zur Paläontologie und Geologie Österreich-Ungarns und des Orients 14, 131-162.

Philip, J. \& Floquet, M. 2000. Late Cenomanian (94.7-93.5), 129-136. In Dercourt, J., Gaetani, M., Vrielynck, B., BarRier, E., Biju-Duval, B., Brunet, M.F., Cadet, J.P., CrasQuin, S. \& SAndulescu, M. (eds) Atlas Peri-Tethys palaeogeographical maps. CCGM/CGMW, Paris.

Richardt, N., Wilmsen, M. \& Niebuhr, B. 2013. Late Cenomanian-Early Turonian facies development and sea-level changes in the Bodenwöhrer Senke (Danubian Cretaceous Group, Bavaria, Germany). Facies 59. DOI 10.1007/s10347-012-0337-x.

SCHLÜTER, C. 1871-1872. Cephalopoden der oberen deutschen Kreide. Palaeontographica 21, 1-24 (1871, 1. Lieferung); 21, 25-120 (1872, 2.-5. Lieferung).

Sharpe, D. 1853-1857. Description of the fossil remains of Mollusca found in the Chalk of England. I, Cephalopoda. Monographs of the Palaeontological Society, London, 1-26, (1853); 27-36, (1855); 37-68, (1857).
Shimer, H.W. \& SHROck, R.R. 1944. Index fossils of North America. 837 pp. Wiley, New York.

Shumard, B.F. 1860. Description of new Cretaceous fossils from Texas. Transactions of the Academy of Sciences of St. Louis 1, 590-610.

Skupin, K. (ed.), Dahm-Arens, H., Michel, G., Vieth-Redemann, A. \& Weber, P. 1989. Geologische Karte von NordrheinWestfalen 1:25.000. Erläuterungen zu Blatt 4418 Wünnenberg. 151 pp. Geologisches Landesamt NRW, Krefeld.

SOWERBY, J. 1812-1822. The mineral conchology of Great Britain; or coloured figures and descriptions of those remains of testaceous animals or shells, which have been preserved at various times and depths in the earth. Volumes 1-4. 383 pls. Meredith, London.

Spath, L.F. 1922. On the Senonian ammonite fauna of Pondoland. Transactions of the Royal Society of South Africa 10, 113-148. DOI 10.1080/00359192209519274

Spath, L.F. 1923. A monograph of the Ammonoidea of the Gault, Part 1. Monographs of the Palaeontological Society, London $353,1-72$.

Spath, L.F. 1926. On new ammonites from the English Chalk. Geological Magazine 63, 77-83. DOI 10.1017/S0016756800083710

Spath, L.F. 1939. Problems of ammonite nomenclature. 6. The genus Pachydiscus Zittel. Geological Magazine 76, 293-296. DOI 10.1017/S0016756800071156

StoliczKa, F. 1863-1866. The fossil Cephalopoda of the Cretaceous rocks of southern India. Ammonitidae with revision of the Nautilidae etc. Memoirs of the Geological Survey of India 1, Palaeontologica Indica 3(1), 41-56 (1863); (2-5), 57-106 (1864); (6-9), 107-154 (1865); (10-13), 155-216 (1866).

Thomel, G. 1992. Ammonites du Cenomanien et du Turonien du sud-est de la France, Tome 2: Considérations sur les faunes d'Ammonites Cénomaniennes et Turoniennes des Chaines Subalpines méridionales (Alpes de Haute-Provence, AlpesMaritimes, Var). 383 pp. Serre Éditeur, Nice.

TRÖGER, K.-A. 1956. Über die Kreideablagerungen des Plauenschen Grundes (sediment-petrographische und biostratonomisch-paläontologische Untersuchungen). Jahrbuch des Staatlichen Museums für Mineralogie und Geologie zu Dresden 2, 22-124.

TRÖGER, K.-A. 1967. Zur Paläontologie, Biostratigraphie und faziellen Ausbildung der unteren Oberkreide (CenomanTuron). Teil I - Paläontologie und Biostratigraphie der Inoceramen des Cenomans und Turons. Abhandlungen des Staatlichen Museums für Mineralogie und Geologie zu Dresden 12, 13-207.

TRÖGER, K.-A. 1968. Bemerkungen zu Hyphantoceras reussianum (d'Orbigny). Freiberger Forschungshefte C 234(3), 45-50.

TRÖGER, K.-A. 1969. Zur Paläontologie, Biostratigraphie und faziellen Ausbildung der unteren Oberkreide (CenomanTuron). Teil II - Stratigraphie und fazielle Ausbildung des Cenomans und Turons in Sachsen, dem nördlichen Harzvorland und dem Ohmgebirge. Abhandlungen des Staatlichen Museums für Mineralogie und Geologie zu Dresden $13,1-70$.

TRÖGER, K.-A. 1989. Problems of Upper Cretaceous inoceramid biostratigraphy and palaeobiogeography in Europe and western Asia, 911-930. In Wiedmann, J. (ed.) Cretaceous of the 
Western Tethys. Proceedings $3^{\text {rd }}$ International Cretaceous Symposium, Tübingen 1987. Schweizerbart, Stuttgart.

Tröger, K.-A. 2003. The Cretaceous of the Elbe valley in Saxony - a review. Carnets de Géologie A03, 1-14.

VAŠIČEK, Z. 1989. Cenomanian ammonites from the Bohemian Cretaceous Basin. Časopis Národního muzea v Praze, Řada přirodovědná 158, 67-77.

Voigt, S., Gale, A.S. \& Voigt, T. 2006. Sea-level changes, carbon cycling and palaeo-climate during the Late Cenomanian of northwest Europe; an integrated palaeo-environmental analysis. Cretaceous Research 27, 836-858. DOI 10.1016/j.cretres.2006.04.005

Voigt, T. 1994. Faziesentwicklung und Ablagerungssequenzen am Rand eines Epikontinentalmeeres - die Sedimentationsgeschichte der Sächsischen Kreide. 130 pp. Unpublished PhD thesis, TU Bergakademie Freiberg.

VoIGT, T. 1998. Entwicklung und Architektur einer fluviatilen Talfüllung - die Niederschöna-Formation im Sächsischen Kreidebecken. Abhandlungen des Staatlichen Museums für Mineralogie und Geologie zu Dresden 43/44, 121-139.

VoigT, T. 1999. Ablagerungsbedingungen und Taphonomie der Schmilka-Formation (Unter-Turon) südlich von Pirna (Sächsisches Kreidebecken). Greifswalder Geowissenschaftliche Beiträge 6, 193-207.

Voigt, T., Voigt, S. \& Tröger, K.-A. 1994. Faziesentwicklung einer ertrunkenen Felsküste - die obercenomane Monzonitklippe westlich von Dresden. Freiberger Forschungshefte $C$ $452,23-34$

Voigt, T., Wiese, F., Eynatten, H. von, Franzke, H.-J. \& Gaupp, R. 2006. Facies evolution of syntectonic Upper Cretaceous deposits in the Subhercynian Cretaceous Basin and adjoining areas (Germany). Zeitschrift der Deutschen Gesellschaft für Geowissenschaften 157(2), 203-243. DOI 10.1127/1860-1804/2006/0157-0203

WANDERER, K. 1909. Die wichtigsten Tierversteinerungen aus der Kreide des Königreiches Sachsen. i-xxii, 81 pp. Verlag von Gustav Fischer, Jena.

WARREN, P.S. 1930. Description of new species of fossils from part of Peace River and Grande Prairie districts, Alberta: New species of fossils from Smoky River and Dunvegan formations, Alberta. Research Council of Alberta Report 21, Appendix, 37-68.

WedeKIND, R. 1916. Über Lobus, Suturallobus und Inzision. Zentralblatt für Mineralogie, Geologie und Paläeontologie for 1916, 185-195.

Wiedmann, J. 1960. Le Crétacé Supérrieur de l'Espange et du Portugal et ses Céphalopodes, 709-764. In Roger, J. (ed.) Colloque sur le Crétacé Supérrieur Français. Comptes Rendus du 84e. Congrés National des Sociétés Savantes, Dijon, France, 1959.

Wiedmann, J. 1964. Le Crétacé Supérrieur de l'Espange et du Portugal et ses Céphalopodes. Estudios Geologicos 20, 107-148.

Wiedmann, J. 1988. Plate tectonics, sea level changes, climate and the relationship to ammonite evolution, provincialism, and mode of life, 737-765. In Wiedmann, J. \& Kullmann, J. (eds) International Conference 'Cephalopods-Present and Past'. Schweizerbart, Stuttgart.
Wilmsen, M. \& Mosavinia, A. 2011. Phenotypic plasticity and taxonomy of Schloenbachia varians (J. Sowerby, 1817). Paläontologische Zeitschrift 85, 169-184. DOI 10.1007/s12542-010-0086-5

Wilmsen, M. \& Niebuhr, B. 2009. Die Kreide der Elbezone. Exkursionsführer und Veröffentlichungen der Deutschen Gesellschaft für Geowissenschaften 241, 199-218.

Wilmsen, M., Niebuhr, B. \& Chellouche, P. 2010a. Occurrence and significance of Cenomanian belemnites in the lower Danubian Cretaceous Group (Bavaria, southern Germany). Acta Geologica Polonica 60, 231-241.

Wilmsen, M., Niebuhr, B., Chellouche, P., Pürner, T. \& KLING, M. 2010b. Facies pattern and sea-level dynamics of the early Late Cretaceous transgression: a case study from the lower Danubian Cretaceous Group (Bavaria, southern Germany). Facies 56, 483-507. DOI 10.1007/s10347-010-0224-2

Wilmsen, M., VodrážKa, R. \& Niebuhr, B. 2011. The Upper Cenomanian and Lower Turonian of Lockwitz (Dresden area, Saxony, Germany): lithofacies, stratigraphy and fauna of a transgressive succession. Freiberger Forschungshefte C 540, $27-45$.

Wright, C.W. \& Kennedy, W.J. 1981. The Ammonoidea of the Plenus Marls and the Middle Chalk. Monographs of the Palaeontological Society, London 560(134), 1-148.

Wright, C.W. \& Kennedy, W.J. 1984. The Ammonoidea of the Lower Chalk. Part I. Monographs of the Palaeontological Society, London 567(137), 1-126.

Wright, C.J. \& Kennedy, W.J. 1990. The Ammonoidea of the Lower Chalk. Part 3. Monographs of the Palaeontological Society, London 585(144), 219-294.

Wright, C.W. \& Kennedy, W.J. 1996. The Ammonoidea of the Lower Chalk. Monographs of the Palaeontological Society, London 601(150), 320-403.

Wright, C.W., Callomon, J.H. \& Howarth, M.K. 1996. Cretaceous Ammonoidea, 1-362. In KAESLER, R.L. (ed.) Treatise on Invertebrate Paleontology, Part L, Mollusca 4. The Geological Survey of America and University of Kansas, Lawrence.

ZabORSKI, P.M.P. 1995. The Upper Cretaceous ammonite Pseudaspidoceras Hyatt, 1903, in north-eastern Nigeria. Bulletin of the British Museum (Natural History), Geology $51,53-72$.

Žítt, J., Nekvasilová, O., Hradecká, L., Svobodová, M. \& ZÁrubA, B. 1998. Rocky coast facies of the Unhošt-Tursko high (Late Cenomanian-Early Turonian, Bohemian Cretaceous Basin). Acta Musei Nationalis Pragae, Series B - historia naturalis 54(3-4), 79-116.

ŽítT, J., VodrážKa, R., Hradecká, L. \& Svobodová, M. 2010. Palaeoenvironments and facies on a progressively flooded rocky island (Upper Cenomanian-Lower Turonian, Bohemian Cretaceous Basin). Journal of the National Museum (Prague), Natural History Series 179(22), 223-234.

ŽítT, J., VodráŽKa, R., HradeckÁ, L., Svobodová, M. \& ZÁGoRŠEK, K. 2006. Late Cretaceous environments and communities as recorded at Chrtníky (Bohemian Cretaceous Basin, Czech Republic). Bulletin of Geosciences 81, 43-79.

DOI 10.3140/bull.geosci.2006.01.043 